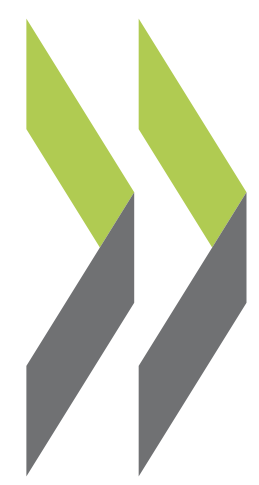

OECD Working Papers on International Investment 2015/02

\title{
Investment Treaties over \\ Time - Treaty Practice and Interpretation in a Changing World
}

\section{Kathryn Gordon,} Joachim Pohl 


\section{OECD WORKING PAPERS ON INTERNATIONAL INVESTMENT}

The international investment working paper series - including policies and trends and the broader implications of multinational enterprise - is designed to make available to a wide readership selected studies by the OECD Investment Committee, OECD Investment Division staff, or by outside consultants working on OECD Investment Committee projects.

The papers are generally available only in their original language English or French with a summary in the other if available. Comment on the series is welcome, and should be sent to investment@oecd.org or the Investment Division, OECD, 2, rue André Pascal, 75775 PARIS CEDEX 16, France

OECD WORKING PAPERS ON INTERNATIONAL INVESTMENT

are published on www.oecd.org/daf/inv/investment-policy/working-papers.htm

OECD Working Papers should not be reported as representing the official views of the OECD or of its member countries. The opinions expressed and arguments employed are those of the authors.

Working Papers describe preliminary results or research in progress by the author(s) and are published to stimulate discussion on a broad range of issues on which the OECD works. Comments on Working Papers are welcomed, and may be sent to investment@oecd.org or the Investment Division, Directorate for Financial and Enterprise Affairs, OECD, 2 rue André-Pascal, 75775 Paris Cedex 16, France.

This document and any map included herein are without prejudice to the status of or sovereignty over any territory, to the delimitation of international frontiers and boundaries and to the name of any territory, city or area.

(C) OECD 2015

Applications for permission to reproduce or translate all or part of this material should be made to: OECD Publishing, rights@oecd.org or by fax 33145249930. 


\title{
Investment treaties over time - Treaty practice and interpretation in a changing world
}

\author{
by \\ Kathryn Gordon and Joachim Pohl
}

\begin{abstract}
Investment treaty law reflects a permanent tension between stability and flexibility. Stability nurtures predictability, while flexibility helps legal systems stay in alignment with changing circumstances and evolving needs. This paper establishes an inventory of the mechanisms in investment treaty law that provide flexibility and surveys relevant treaty practice.

The paper: analyses the drivers of change in investment treaty law; provides an inventory of countries' options - and limits - to alter their positioning vis-à-vis investment treaty law through 'exit' and 'voice'; and analyses treaty provisions on, and States' use of, flexibility in investment treaty law.

The paper finds that most treaties provide for little or no mechanism for countries to influence the use and interpretation of investment treaty law. The paper further finds that treaty provisions for 'exit' are likewise geared to provide stability rather than flexibility. Analysis of State practice presented in the paper shows that States rarely make use of the mechanisms available to them to influence treaty use and interpretation and that 'exit' from the system has likewise been rare so far.
\end{abstract}

Approved by Pierre Poret, Deputy Director, OECD Directorate for Financial and Enterprise Affairs

JEL Classification: F21; F53; K33; N40; P45

Keywords: investment treaties, international investment agreements, investment protection, international investment law. 
Table of Contents

Executive Summary..........................................................................................................................................................5

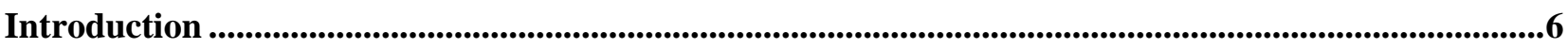

1. Drivers of countries' re-evaluation of investment treaty law .......................................................9

Structural change in the global economy changes countries' perspectives .......................................9

Updating legal and economic analyses of treaty implications after ratification ..................................

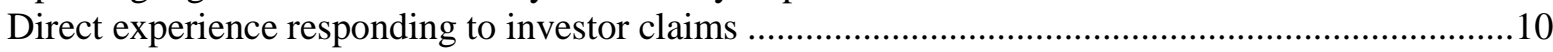

Learning from experiences responding to treaty-based claims ........................................................

2. The roles of States and tribunals in investment treaty interpretation .............................................12

3. Exit and Voice - Strategies for adapting investment law to changing circumstances .................16

4. Exit - treaty provisions and state practice on IIA termination...................................................18

Lock in effects - estimating their size and prevalence ..................................................................20

5. Options for voice - how governments can influence their positioning in the international

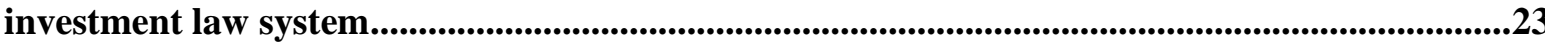

a. Means that States may use to influence the interpretation of international investment

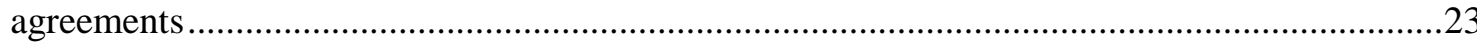

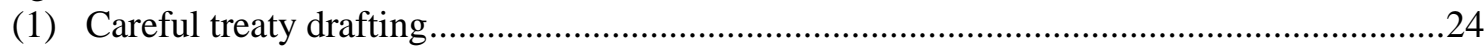

(2) Joint or unilateral instruments clarifying meaning and treaty parties' intent........................25

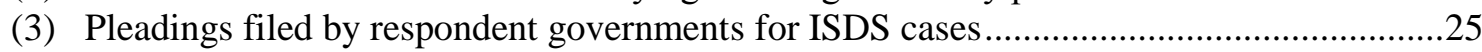

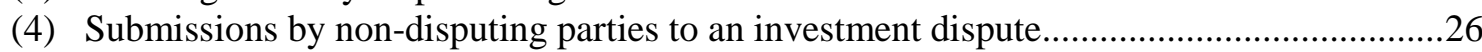

b. Built-in treaty mechanisms that permit States to influence treaty interpretation .........................26

(1) Ad hoc interpretations and authoritative interpretations by treaty institutions ...................26

(2) Joint determinations on the nature of tax or prudential measures.......................................29

(3) Other consultation mechanisms that allow states to influence treaty interpretations ..........31

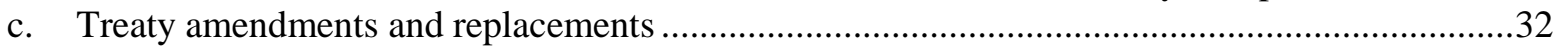

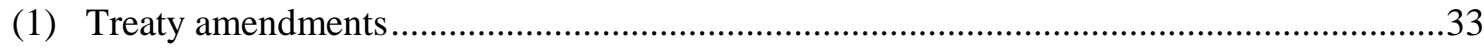

(2) Investment treaty replacements - renegotiations resulting in new treaties...........................35

6. Conclusions .......................................................................................................................................................40

\section{Figures}

Figure 1. Projection of duration of continued validity of treaties after termination....................................21

Figure 2. Projection of future validity of treaties concluded by selected countries .................................22

Figure 3. The dynamics of investment treaty formation and replacement ................................................36 


\section{Executive Summary}

Investment treaty law, like all systems of law, reflects a permanent tension between stability and flexibility. Stability nurtures predictability, while flexibility helps legal systems stay in alignment with changing circumstances and evolving needs. This paper establishes an inventory of the mechanisms in investment treaty law that provide flexibility and provides supporting surveys of relevant treaty practice.

The paper begins with a brief overview of the drivers of change in investment treaty law (e.g. changing structural conditions in the global economy, growing country experiences as respondents, and treaty partners' learning from this experience). However, the paper emphasises at the outset that so far, many countries are confident of the benefits of the current state of investment treaty law in general and of their treaty practice in particular.

The paper then provides an inventory of the options available to countries seeking to alter their positioning vis-à-vis investment treaty law. These options are organised into two broad categories. The first option is 'exit', the most drastic approach to change, in which countries seek to leave the treaty system entirely. To date, exit from investment treaty obligations has been rare, with nineteen treaties known to have been terminated unilaterally, and two treaties terminated consensually. The results of a survey of treaty provisions relating to exit are provided using the OECD's database of 2,061 treaties to which FOI participants are party. A simulation is run using a scenario of immediate and unilateral termination all of the treaties in the sample as soon as such termination is permitted under the treaty. The simulation uses as inputs the 2,061 treaties' provisions on validity periods (these prohibit unilateral termination by treaty partners for a fixed period of time) and survival clauses (which extend certain treaty protections for specified - usually already made - investments). Taking 2014 as the starting year for the simulation, the results show that, although two thirds of treaties in the sample could be unilaterally terminated within a year's time, 90 per cent of the treaties in the sample would continue to have some binding effect until at least 2025. Thus, investment treaties appear, on average, to provide for significant stability in treaty-based protections for covered investors via their validity and survival clauses.

The second option for influencing countries' positioning vis-à-vis investment treaty law is 'voice'. Voice in this context means that treaty partners use unilateral or multilateral tools to influence the use and interpretation of investment treaty law. The paper examines treaty parties' options for voice and maps relevant treaty practice. Options for voice include: crafting of clear treaty language during negotiations, filings by non-disputing parties for ISDS cases, other evidence of state practice such as model treaties, authoritative interpretations and other statements clarifying the meaning of treaty provisions, treaty amendments and protocols and treaty replacement through renegotiation.

The survey of treaty practice shows that by far the most common approach is silence on partners' options for influencing treaty interpretation. A few countries provide for filings by non-respondent treaty partners and authoritative interpretations, but these are extremely rare and concentrated almost exclusively among countries located in the Americas. A survey of investment treaty replacements through renegotiation shows that replacement is also rare, but has, to a limited extent, made treaties more similar to one another (that is, has involved a very partial movement toward convergence). 
The general question of 'treaties over time' reflects the tension between the requirements of stability and change in the law of treaties. On the one hand, it is generally the purpose of the law of treaties to provide stability in the face of evolving circumstances. On the other hand, legal systems must also leave room for the consideration of subsequent developments in order to ensure meaningful respect for the agreement of the parties and identification of its limits.

George Nolte, Rapporteur of the International Law Commission ${ }^{1}$ on the project 'Treaties over time'

\section{Introduction}

As the above quote indicates, treaty law - and, indeed, all systems of law - embody a permanent tension between stability and flexibility. Stability nurtures predictability and facilitates compliance, while flexibility helps legal systems stay in alignment with evolving needs and circumstances. ${ }^{2}$

Investment treaty law needs to adapt in order to respond to the evolving needs of both investors and treaty partners in a dynamic global economy. Pressures for adaptation may also emerge as the main actors in the system - governments, investors and the arbitration bar - learn how investment agreements are understood and used, especially in the context of dispute resolution. At the same time, if investment treaties are to succeed in their aim of promoting foreign investment, then they need to provide a stable framework for this investment.

Thus, parties to investment treaties (as well as investors) have interests both in treaty stability and in securing some flexibility - that is, in providing tools they can use to influence the way that their treaties are used and interpreted. A number of options are available to governments wishing to exercise such influence. This paper and a related study carried out on demand of Roundtable participants ${ }^{3}$ provide an inventory of such options along with related surveys of relevant treaty practice. The paper responds to a request made at the October 2012 Freedom of Investment (FOI) Roundtable 17 for work exploring "the role of States in the interpretation of investment treaties".

At the outset it should be stressed that different governments assign different degrees of importance to the stability and flexibility. Some are highly satisfied with their investment treaty practice and their experiences with treaty-based investor state arbitration. They therefore generally favour keeping their treaties and the ISDS system as a whole unchanged - for them, flexibility may not be a high priority.

In contrast, other countries harbour doubts about the current state of international investment law and its dispute settlement institutions. These doubts have manifested themselves in a variety of ways. For example:

- Brazil has never ratified any of the investment treaties it negotiated and has no plans to do so;

1 Georg Nolte, Rapporteur of the International Law Commission. 2008 Recommendation: See Annex A, 'Treaties over Time, in Particular: Subsequent Agreement and Practice'. A/63/10 International Law Commission. Page 365.

2 For an economic analysis of stability and flexibility in investment treaty law, see Anne van Aaken (2009) "International Investment Law between Commitment and Flexibility: A Contract Theory Approach", Journal of International Economic Law. 12(2) pp. 507-508.

3 Pohl, J. (2013), “Temporal Validity of International Investment Agreements: A Large Sample Survey of Treaty Provisions”, OECD Working Papers on International Investment, 2013/04. 
- Australia has declared that it will no longer seek provisions on investor state dispute settlement (ISDS) in its investment treaties, citing concerns about creating substantive and procedural rights for foreign investors that are not available to Australian investors in Australia; ${ }^{4}$

- South Africa has begun to terminate treaties it has concluded earlier and to develop an investment law that would provide a domestic legislative framework that fulfils some of the investment protection functions of investment treaties. The draft law seeks to modernise and improve South Africa's investment protection regime and to ensure consistent treatment of all foreign investors. ${ }^{5}$ India and Indonesia have also declared that they sought to terminate and replace at least some of their BITs, and both countries have begun to do so;

- Bolivia, Ecuador and Venezuela ${ }^{6}$ have withdrawn from the International Centre for the Settlement of Investment Disputes (ICSID), a key part of investment law's institutional framework;

- Some countries have discontinued negotiating IIAs a while ago; Norway and Poland for instance, have not signed any bilateral IIA in the past 15 years or more.

The current paper does not take a position on the complex question of whether a fundamental reevaluation of investment law is warranted. However, the fact that a number of governments seem to have concerns about the system has implications even for those governments that are confident about the benefits of the current state of investment treaty law and of their treaty practice: Over the medium term, they might lose important treaty partners that are less comfortable with current arrangements or they may find it more difficult to convince potential treaty partners to negotiate new treaties. All countries therefore have an interest in nurturing a consensus among countries with stakes in investment treaty law that the treaty system is capable of responding to evolving needs and circumstances.

Collective understanding of and satisfaction with the benefits of an international investment law system is thus in the interest of all countries. This paper seeks to enhance the understanding of the options available to governments for adapting treaty practice to maintain mutually beneficial treaty relations despite changing circumstances.

The intent of the present paper is to complement the law literature and other international dialogue processes (e.g. at the UN International Law Commission's project on Treaties over Time ${ }^{7}$ ) by providing

4 After a change in the Australian government, the country's policy has been amended in late 2013. Henceforth, the Australian Government considers ISDS provisions in FTAs on a case-by-case basis (the Australia-Korea FTA (2014), signed in April 2014, contains an ISDS mechanism, while the Japan-Australia EPA (2014), signed in July 2014, does not.

5 See, New Law to Deal with Compensating Foreign Investors For Expropriation, Business Week, posted on 18 February 2013 at http://bilaterals.org/spip.php?article22727 and Termination of bilateral investment treaties won't harm relations by South Africa's Minister of Trade and Industry Rob Davies, published in Business Day (South Africa) on 19 July 2013 and available at http://bilaterals.org/?termination-of-bilateral. The draft Promotion and Protection of Investment Bill, 2013, approved for public comments at the Cabinet meeting of 23 October 2013, is available at www.tralac.org/files/2013/11/Promotion-and-protection-of-investment-bill2013-Invitation-for-public-comment.pdf.

6 Bolivia withdrew on 2 May 2007, Ecuador on 6 July 2009, and Venezuela on 24 January 2012.

7 The present paper extends to the investment law context a line of dialogue and analysis that is being pursued for international law, more generally, by the United Nations International Law Commission in its project on "Treaties over Time". 
factual, survey-based information on how States' investment treaty practices and other measures can and are used to influence the interpretation of their investment treaties.

The paper is organised in six sections:

1. Drivers of countries' re-evaluation of investment treaty law

2. The roles of States and tribunals in investment treaty interpretation

3. Exit and Voice - Strategies for adapting investment law to changing circumstances

4. Exit - treaty provisions and state practice on IIA termination

5. Options for voice - how governments can influence their positioning in the international investment law system

6. Conclusions 


\section{Drivers of countries' re-evaluation of investment treaty law}

As just noted, a number of countries have indicated that they have changed or are re-evaluating their approach to various aspects of international investment law. This section reviews factors that may underpin these developments.

\section{Structural change in the global economy changes countries' perspectives}

Each investment treaty reflects a specific approach to protecting covered investors and managing legal risks for treaty partners. As the distinction between capital-exporting and capital-importing countries continues to fade - many countries are now "a bit of both" ${ }^{8}$ - countries' perceived self-interests in relation to investment treaties may have evolved. Investment protection may gain in importance to countries with emerging capital export activities while management of legal risks may assume greater importance to countries that have traditionally been capital exporters but now receive significant capital inflows. Structural change may therefore lead to a re-evaluation of treaty practice and may also promote a greater commonality of interests among treaty partners. ${ }^{9}$

\section{Updating legal and economic analyses of treaty implications after ratification}

Studies of the history of investment treaty formation suggest that a considerable number of countries entered into these treaties with little prior analysis or awareness of their legal implications and economic costs and benefits. A 2011 study ${ }^{10}$ based on 30 interviews with BIT 'stakeholders' involved in the BIT formation process (e.g. treaty negotiators) from 13 developing countries documents the degree to which these 'stakeholders' were unaware of the legal implications of these treaties.

Another, complementary view of investment treaty formation emphasises the fact that countries adopting investment treaties had multiple reasons for signing BITs - reasons that related to both domestic and international politics. ${ }^{11}$ Protecting covered foreign investments and enhancing credible commitments to treaty compliance may not have been foremost among these reasons, and deep legal and economic analysis may not have seemed warranted to some treaty adopters.

8 See, for example, OECD Secretary-General Angel Gurria's presentation to US Council for International Business Global Investment Conference, Washington DC, 10 March 2010.

9 See Kenneth J Vandevelde. 'A Brief History of International Investment Agreements', 12 U.C. Davis J. Int'l L. \& Pol'y 157 (2005), reprinted in The Effect of Bilateral Investment Treaties and Double Taxation Treaties on Foreign Direct Investment Flows 2 (Karl P. Sauvant and Lisa E. Sachs, eds., New York: Oxford University Press, 2009). See also José Alvarez "The Once and Future Foreign Investment Regime," in Looking to the Future: Essays on International Law in Honor of W. Michael Reisman (Mahnoush Arsanjani, Jacob Katz Cogan, Robert D. Sloane and Siegried Wiessner, eds., Martinus Nijhoff, 2010).

10 See Lauge Skovgaard Poulsen and Emma Aisbett "When the Claim Hits: Bilateral Investment Treaties and Bounded Rational Learning” (29 July 2011) Crawford School Research Paper no. 5. Australian National University. In particular, see Section 2 on 'Qualitative Evidence'.

11 José Alvarez "The Once and Future Foreign Investment Regime," in: Looking to the Future: Essays on International Law in Honor of W. Michael Reisman (Mahnoush Arsanjani, Jacob Katz Cogan, Robert D. Sloane and Siegried Wiessner, eds., Martinus Nijhoff, 2010) at pages 620-622. 
Nevertheless, countries that, at one time and for various reasons, had not given in-depth consideration to investment treaties' language prior to adoption - or that realised only later how the language in the treaty was understood by tribunals - may now feel a need to adjust treaty practice, especially as the number of treaty-based investor-state disputes grows and awards gradually shed more light on how treaty provisions are used and interpreted.

\section{Direct experience responding to investor claims}

The annual number of investment treaty claims has increased rapidly since the $1990 \mathrm{~s}^{12}$ and most countries with treaties now have direct experience responding to claims; however, the extent of this experience varies widely. According to OECD Secretariat calculations, ${ }^{13}$ of the 173 countries that have investment treaties in force, 91 - or about 53\% - have responded to at least one treaty-based investor claim. More specifically, $47 \%$ of the high income countries with treaties have responded to at least one claim (16 out of the 34 countries), ${ }^{14}$ while only a slightly higher proportion, $54 \%$ of the low and middle income countries with treaties have been respondents ( 75 of the 139 countries). ${ }^{15}$

Of the total of 401 investor-state claims identified by the OECD Secretariat, 66 have high income countries as respondents, while low and middle income countries are respondents for 335 of these claims. The number of cases handled by responding countries varied greatly: Argentina had the highest number of identified cases (39 cases) while 31 of the responding countries have faced only one case.

The upsurge in investor-state arbitration cases may have raised host governments' awareness of treaty implications as well as the broader political visibility of investment treaties.

\section{Learning from experiences responding to treaty-based claims}

Countries' experiences as respondents in ISDS cases may not only raise awareness of investment treaties' legal implications, but also cause governments to re-evaluate certain treaty practices. ${ }^{16}$ Indeed, an empirical study of BIT negotiations shows that having been a respondent in a treaty-based claim is a

12 See, for example, UNCTAD World Investment Report 2013, page 111.

13 Data presented in this paragraph was tabulated by the OECD Secretariat from treaty and case information available on the ICSID website (https://icsid.worldbank.org) and the ITA Law website (www.italaw.com) in late July 2013. Under this sampling scheme, a country is counted as having been a respondent if any trace of legal filings regarding an arbitration claim can be found on either of these two websites.

The high income OECD countries with treaties that have responded to at least one claim are: Australia (1 case), Belgium (1 case), Canada (15 cases), Chile (5 cases), Czech Republic (16 cases), Estonia (4 cases), Germany (2 cases), Greece (1 case), Korea (1 case), Spain (4 cases), United Kingdom (1 case), and United States (10 cases).

The categorisation of high income and low and middle income countries follows the World Bank Atlas Method. 'Low and middle income' countries' are those that the World Bank categorises as low income, lower middle income or upper middle income.

Some FOI participants have reported very positive experiences when they responded to ISDS claims. See, notably, Germany's views presented to FOI Roundtable 15 (December 201) regarding its negotiations with a multinational enterprise conducted in the shadow of an ISDS claim. A summary of this presentation is available in the Summary of FOI Roundtable 15, page 5. 
strong, statistically significant predictor of countries' BIT renegotiation activity ${ }^{17}$ - it would appear that experiences responding to claims cause governments to want to realign their treaty practice.

According to one commentator, this learning process for treaty partners may have been complicated by the structure of investment treaty law: “... investment treaty jurisprudence can be hard to access and assess. Nowhere is it required that all investment awards be published, though many are. These awards are proliferating, which makes it time-consuming to stay abreast of developments. There is no neat hierarchy or structure for sorting published decisions to identify seminal awards. Without a strict doctrine of precedent, it takes a certain number of cases before states are likely to apprehend the jurisprudential trends. Even then, states may wish to respond but lack the budget to do so effectively."18

As transparency standards have improved and legal services specialising in providing information on investor-state claims have become available, governments are better informed about how investment treaties are being used and interpreted. This greater information may, in some cases, put countries in a position to evaluate treaty use and arbitral decision making and to seek to gain more control over interpretations.

$17 \quad$ Yoram Haftel/Alexander Thompsom. "When Do States Renegotiate International Agreements? A Case of Bilateral Investment Treaties" (unpublished working paper, November 2013).

18 Anthea Roberts, 'Power and Persuasion in Investment Treaty Interpretation: The Dual Role of States' (12 January 2010). American Journal of International Law, Vol. 104. page 195. 


\section{The roles of States and tribunals in investment treaty interpretation ${ }^{19}$}

Investment treaties set forth commitments by State parties to respect standards of investment protection for covered foreign investors. In order to enhance the credibility of their treaty commitments and to promote investment treaty compliance, governments have adopted an unusual approach: ${ }^{20}$ under the ISDS provisions that are an almost universal feature of investment treaties, ${ }^{21}$ investors may bring treatybased claims against States before international arbitration tribunals tasked with settling the disputes. The provisions create a framework for private enforcement of States' investment treaty commitments. Thus, international arbitration is a key component of investment law's approach to enhancing compliance with investment treaty commitments.

Another key aspect of international investment law is that some investment treaty commitments involve standards of government treatment of foreign investors (e.g. "fair and equitable treatment", "national treatment") that are (perhaps unavoidably) difficult to describe in precise terms. Lack of precise wording for many investment treaty provisions ${ }^{22}$ amplifies the need for interpretation that allows these broadly worded provisions to be applied to specific fact situations. Thus, interpretation under investment treaty law is a particularly important requirement of dispute settlement system (though it is obviously very important in all such systems). States and arbitration tribunals have shared, but differentiated, roles in the interpretive process - basically states provide guidance in various forms for interpretations, while arbitrators seek to settle investor state disputes by applying the relevant investment treaty provisions and other guidance to a particular fact situation relating to a specific dispute.

As is typical of international law in general, investment treaty arbitration tribunals are not tasked with creating jurisprudence, but with resolving disputes. In practice, however (and as will be documented below), arbitral panels, even if they do not create jurisprudence, nevertheless contribute to the accumulation of a body of thought on the meaning of investment treaty terms that influences other

19 This section and subsequent sections draw on Anthea Roberts, 'Power and Persuasion in Investment Treaty Interpretation: The Dual Role of States’ (January 12, 2010). American Journal of International Law, Vol. 104.

Unusual, that is, compared with approaches adopted in other bodies of international law, such as human rights and trade law. See Gaukrodger, D. and K. Gordon (2012), "Investor-State Dispute Settlement: A Scoping Paper for the Investment Policy Community", OECD Working Papers on International Investment, 2012/03, pp. 10-13.

See Pohl, J., K. Mashigo and A. Nohen (2012), "Dispute Settlement Provisions in International Investment Agreements: A Large Sample Survey”, OECD Working Papers on International Investment, 2012/02.

See also, for example, Andrea Bjorklund, 'Investment Treaty Arbitral Decisions as Jurisprudence Constante' (December 23, 2008). UC Davis Legal Studies Research Paper No. 158. Available at SSRN: http://ssrn.com/abstract=1319834 or dx.doi.org/10.2139/ssrn.1319834 . Her abstract states: "The content of the most frequently invoked substantive treaty provisions ... is far from clear. Furthermore, procedural matters, such as decisions regarding the place of arbitration or the allocation of costs, play an increasingly important role in investment arbitrations but are also not addressed thoroughly in the treaties themselves." This latter finding is supported by Pohl, J., K. Mashigo and A. Nohen (2012), "Dispute Settlement Provisions in International Investment Agreements: A Large Sample Survey", OECD Working Papers on International Investment, 2012/02. 
arbitrators' decisions. ${ }^{23}$ Thus, investment arbitration results not only in the settling of disputes, but also in an accumulation of understandings and a clarification of the meaning of investment treaty law.

In contrast, the role of states in influencing the interpretation of investment treaties is (or should be) to make judicious use of the set of tools made available to them by international law and in the investment treaties themselves in order to provide appropriate guidance for the use and interpretation of investment treaties by all treaty users, and especially arbitrators. Channels for influencing treaty interpretation include: careful crafting of treaties, documenting the intent of treaty parties prior to adopting treaties, using various tools (e.g. authoritative interpretations) for influencing interpretations after the investment treaty has been adopted, and, in cases where more substantial adjustments appear necessary, amendment or replacement of the treaty.

In summary, investment treaty law is characterised by sharing of responsibilities for treaty interpretation between governments - who provide guidance for interpretation on behalf of their citizens and arbitrators - who have received delegated authority to interpret treaties in specific fact situations.

Yet, it cannot be taken for granted that this sharing of roles has always worked smoothly. Some commentators question whether States have fully assumed their responsibilities in influencing treaty interpretation and suggest that panels make decisions largely by reference to other tribunals' awards and to academic opinion. For example, Professor Anthea Roberts asserts that tribunals' decisions 'can convey the impression of a closed-circuit feedback loop between tribunals and academics, unconstrained by the discipline of the treaty parties' practice or expectations." ${ }^{24}$

A statistical study of the legal reasoning used by ICSID tribunals in treaty-based cases finds that decisions of other arbitration panels are, by far, the most cited external references in these awards, accounting for $38 \%$ of the total interpretive citations in the 98 awards surveyed (Table 1). ${ }^{25}$ Legal doctrine (academic articles) are cited in 73 of the 98 ICSID decisions studied and account for $16 \%$ of total interpretive sources cited in decisions. Sources from treaty parties (e.g. preparatory work, the treaties themselves ${ }^{26}$ model treaties, ${ }^{27}$ and object and purpose as described in the treaty itself) account for only $29 \%$ of interpretive sources cited. These statistics provide some support for the view that the process of

23 Quote from Anthea Roberts, 'Power and Persuasion in Investment Treaty Interpretation: The Dual Role of States' (January 12, 2010). American Journal of International Law, Vol. 104, page 189 (where treaty language is described as being "broad and vague").

Anthea Roberts, 'Power and Persuasion in Investment Treaty Interpretation: The Dual Role of States' (January 12, 2010). American Journal of International Law, Vol. 104, page 190.

Ole Kristian Fauchald (2008), ‘The Legal Reasoning of ICSID Tribunals - An Empirical Analysis.' European Journal of International Law. Vol 19 no. 2.

26 Fauchald's study shows inter alia that arbitral panels rely relatively little on investment treaties when considering the 'object and purpose' of these treaties. He states that, "in a clear majority of decisions, the tribunals did not refer to any source for the statements concerning the object and purpose. The lack of identification may indicate that tribunals were of the opinion that the object and purpose was evident and that no reference was needed, or that tribunals merely based their arguments on their own opinion concerning the object and purpose." Ole Kristian Fauchald (2008), 'The Legal Reasoning of ICSID Tribunals - An Empirical Analysis.' European Journal of International Law. Vol 19 no. 2, page 322.

Fauchald finds that 5 decisions refer to model investment treaties, all of which are to the US model treaty, Ole Kristian Fauchald (2008), 'The Legal Reasoning of ICSID Tribunals - An Empirical Analysis.' European Journal of International Law. Vol 19 no. 2, page 348. 
interpretation of investment treaties in an arbitration context consists largely of a dialogue among arbitrators and academics, with these sources alone accounting for over half of interpretive citations.

Table 1. Interpretive Citations in 98 ICSID Arbitral Decisions: Sources of Influence

\begin{tabular}{|c|c|c|}
\hline & $\begin{array}{l}\text { No. of times } \\
\text { source cited }\end{array}$ & $\begin{array}{l}\% \text { of total } \\
\text { citations }\end{array}$ \\
\hline ICSID case law & 90 & $20 \%$ \\
\hline UNCITRAL case law & 30 & $7 \%$ \\
\hline Case law from Iran US claims & 22 & $5 \%$ \\
\hline Case law from other investment tribunals & 30 & $7 \%$ \\
\hline Total for ad hoc tribunals & 172 & $38 \%$ \\
\hline Legal doctrine (academic publications) & 73 & $16 \%$ \\
\hline State practice and object and purpose (e.g. investment treaties, model treaties) & 52 & $12 \%$ \\
\hline Preparatory work & 25 & $6 \%$ \\
\hline Object and purpose & 48 & $11 \%$ \\
\hline Agreement between parties to treaties & 6 & $1 \%$ \\
\hline Total sources from treaty parties & 131 & $29 \%$ \\
\hline ICJ case law & 46 & $10 \%$ \\
\hline Customary international law & 24 & $5 \%$ \\
\hline General principles of law & 4 & $1 \%$ \\
\hline Total international and general law sources & 74 & $16 \%$ \\
\hline TOTAL OF ALL INTERPRETIVE CITATIONS & 450 & $100 \%$ \\
\hline
\end{tabular}

Source: OECD calculations from statistics provided in Ole Kristian Fauchald 'The Legal Reasoning of ICSID Tribunals - An Empirical Analysis.' The European Journal of International Law (2008) Vol. 19 no. 2 pages 356-357.

The responsibility for this state of affairs does not necessarily lie only with the arbitration panels. States may make too little use of the options to offer interpretive guidance to arbitration panels. OECD surveys of treaty provisions on ISDS $^{28}$ and on references in IIAs to environmental concerns, labour standards, human rights and anti-corruption in investment agreements ${ }^{29}$ suggest that for the most part, states have chosen to remain silent on many important matters that influence their treaty obligations or dispute settlement procedures. Although there is some indication that States provide increasing guidance on the conduct of ISDS, 'light regulation' continues to dominate on procedural matters. ${ }^{30}$ If States provide

28 Pohl, J., K. Mashigo and A. Nohen (2012), "Dispute Settlement Provisions in International Investment Agreements: A Large Sample Survey”, OECD Working Papers on International Investment, 2012/02.

Gordon, K., J. Pohl and M. Bouchard (2014), "Investment Treaty Law, Sustainable Development and Responsible Business Conduct: A Fact Finding Survey", OECD Working Papers on International Investment, 2014/01. Agreements: A Large Sample Survey”, OECD Working Papers on International Investment, 2012/02, page 39. 
no or unclear guidance on key issues, it can be expected that arbitration panels will look to other sources for clarification.

The present paper does not adopt a position on whether or not treaty parties should engage more deeply in this interpretation process. However, if this is to be the case, treaty parties need to assume their responsibilities by tighter treaty drafting and by greater use of other channels of influence. This paper establishes options available to states in reinforcing this role. 


\section{Exit and Voice - Strategies for adapting investment law to changing circumstances}

Parties to investment treaties have major stakes in how investment treaties are used and interpreted they are respondents in all treaty-based claims and their investment treaty commitments can have farreaching implications for public policy, fiscal positions and the policy making process. They therefore have a responsibility to ensure - through overseeing and influencing treaty interpretation - that the treaties and associated dispute settlement procedures fulfil their intended purposes.

States have a number of options as they seek to influence the use and interpretation of their investment treaties. The discussion in the present paper is organised by reference to an economic/organisational concept that is increasingly used in legal research: exit and voice. ${ }^{31}$

'Exit' is the act of eliminating exposure to a particular organisation or system (e.g. exposure to ISDS claims) by leaving that system. In the case of investment treaty law, exit involves renunciation of treaties and/or withdrawal from arbitration centres and conventions. 'Voice', in contrast, involves remaining in the system but trying to change it as an active participant.

The notion of 'exit and voice' posits a close link between institutional arrangements between the two - if the scope for voice is too limited, then incentives for exit are strengthened. As one commentator puts it in reference to investment treaty law, "dissatisfied States may also demand greater voice, which is a metaphor for their quest to affect or amplify their control over the decision making process. The States within the system seek to make the decision makers (here tribunals) more responsive to their concerns so that they will not feel the need to exit the system. Exit and voice exist in a state of tension: States will have greater incentives to demand an effective voice when exit options are limited...".32

Quite a large range of options is available to governments to exit from the investment treaty system or to exercise voice within this system and its constituting investment treaties. These options are summarised in Table 2. The remainder of this paper explores these options in greater detail, with a particular emphasis on providing data on relevant treaty practice.

31 This way of categorising the options available to states in influencing investment treaty interpretation is due to Anthea Roberts, 'Power and Persuasion in Investment Treaty Interpretation: The Dual Role of States' (12 January 2010). American Journal of International Law, Vol. 104, in particular pages 191-195. Her categorisation is in turn based on Albert Hirschman (1970) Exit, Voice, and Loyalty: Responses to Decline in Firms, Organizations, and States. Cambridge, MA: Harvard University Press. 
Table 2. Government options for exit and voice in investment treaty law

\begin{tabular}{|c|c|}
\hline Exit & Voice \\
\hline $\begin{array}{l}\text { - Unilateral denunciation or withdrawal from treaties } \\
\text { - Termination of treaties by mutual agreement of treaty } \\
\text { partners }\end{array}$ & 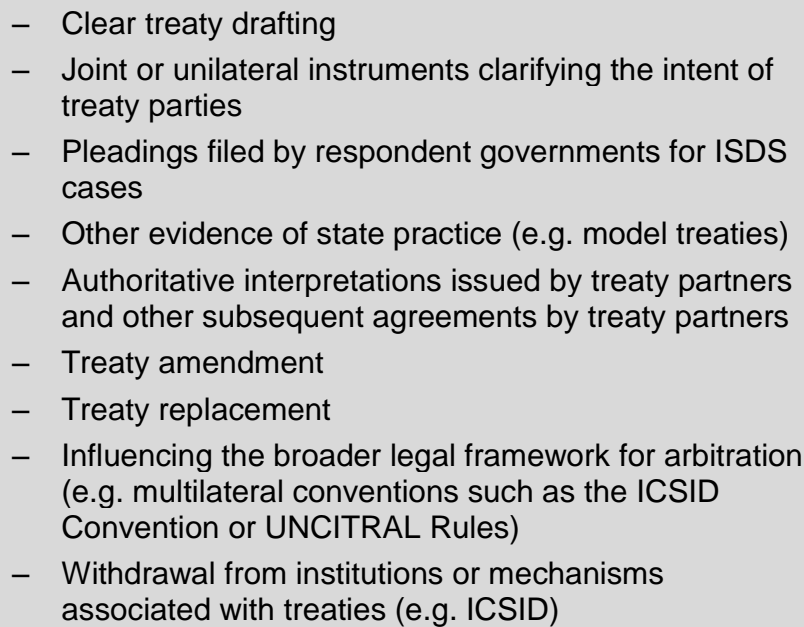 \\
\hline
\end{tabular}

Source: OECD.

In practice, countries do indeed use these possibilities for exit and voice. For instance, among the 1,896 IIAs in a sample that countries have brought into force since 1959, at least 170 treaties, or $9 \%$ of the subsample, have been amended, complemented after their signature by protocols, replaced, denounced, or ended by mutual agreement. ${ }^{33}$

The degree to which individual countries express these forms of voice or exit from their treaties varies significantly: For instance, while 10 countries have not amended, complemented, replaced or denounced any of their treaties since they were brought into force, three countries have amended, complemented later by protocols, replaced, denounced, or ended by mutual agreement between $25 \%$ and $35 \%$ of their treaties.

The frequency of exit and expression of voice has increased since the mid-1990s, but this finding needs to be interpreted with caution; the number of IIAs has also multiplied since about the same time, thus augmenting the number of treaties from which countries could exit or express voice on.

33 The sample is developed based on the treaty sample of 2,061 bilateral IIAs that was developed for the OECD study Pohl, J. (2013), “Temporal Validity of International Investment Agreements: A Large Sample Survey of Treaty Provisions", OECD Working Papers on International Investment, 2013/04. The subset of 1,896 IIAs mentioned here only considers treaties in this sample that are known to have been brought into force. 


\section{Exit - treaty provisions and state practice on IIA termination}

One means to influence treaty interpretation is simply to terminate the treaty, thereby doing away with the need to interpret it. Investment treaties contain provisions that regulate how countries may terminate them unilaterally. In keeping with the treaties' investment promotion objectives, these provisions appear to be designed to reinforce stability and predictability by slowing down the process of treaty exit. Thus, investment treaties tend, by design, to "lock in" treaty partners to their commitments in ways that give the treaty continuing effect for many years.

This section presents the results of a detailed survey of 'exit' or termination provisions of investment treaties in a sample of 2,061 IIAs (defined as BITs and other bilateral treaties such as FTAs and EPAs that contain investment chapters). ${ }^{34}$

The survey maps the variety and complexity of provisions on treaty validity. ${ }^{35}$ Key findings include:

- Treaty termination has been an extremely rare event until very recently, but its frequency has accelerated in the most recent past. Overall, only nineteen investment treaties, or 1\% of the 1,896 treaties in the treaty sample that are known to have been brought into force by September 2014, are known to have been denounced unilaterally at the time of the conduct of the survey. ${ }^{36}$ In one additional case, one country has withdrawn from a trilateral treaty, but the treaty is still in force among the remaining two treaty partners. ${ }^{37}$ Two treaties are known to have been ended by mutual consent, not counting replacements of treaties. ${ }^{38}$ All but three of the nineteen treaty terminations have been declared since 2012, and more terminations are likely, as some countries - India,

$34 \quad$ A full description of the methodology and findings of this survey is available in Pohl, J. (2013), "Temporal Validity of International Investment Agreements: A Large Sample Survey of Treaty Provisions", OECD Working Papers on International Investment, 2013/04. The data presented in the present document has been updated as of September 2014, which explains slight differences in numbers between the two studies.

Following the Vienna Convention on the Law of Treaties, this section uses the term "validity" to designate the state in which an investment treaty is in force. In addition to their periods of validity, most investment treaties also contain "survival" clauses that extend treaty protections for qualifying investors (those that have made an investment covered by the treaty prior to the treaty being terminated) for a period defined in the treaty.

According to information available to the OECD Secretariat as of September 2014, unilateral denunciation or withdrawal occurred in relation to the following treaties: Argentina-India BIT (1999); Belgium/LuxembourgSouth Africa BIT (1998); Denmark-Indonesia BIT (2007); Finland-South Africa BIT (1998); France-Indonesia BIT (1973); France-South Africa BIT (1995); Germany-Bolivia BIT (1987); Germany-South Africa BIT (1995); Indonesia-Norway BIT (1991); Indonesia-Slovakia BIT (1994); Netherlands-South Africa BIT (1995); Netherlands-Venezuela BIT (1991); Romania-Ecuador BIT (1996); South Africa-Spain BIT (1998); South Africa-Sweden BIT (1998); South Africa-Switzerland BIT (1995); South Africa-United Kingdom BIT (1994); Spain-Bolivia BIT (2001); United States-Bolivia BIT (1998). (The in-force status of the treaty is not indicated in this list.)

Venezuela withdrew from the Colombia-Mexico FTA (1994) - initially a trilateral treaty, which continues to be in force among Colombia and Mexico.

The termination of the Czech Republic-Italy BIT (1996) became effective on 1 May 2009, and the termination of the Czech Republic-Ireland BIT (1996) became effective on 1 December 2011. 
Indonesia and South Africa as well as Bolivia - have announced their intention to terminate some or all of their treaties.

- Complexity of exit provisions. The survey shows a fair degree of complexity of exit provisions within individual treaties. For instance, treaties define up to seven different time sequences to establish a combination of initial validity periods, extension periods, advance notice periods, and 'survival clauses' during which the treaty continues to have effects for existing investments.

- Initial validity periods for investment treaties average about 10 years. Most investment treaties establish initial validity periods that define set periods during which the treaty cannot be terminated unilaterally. The distribution of initial validity periods over time shows convergence towards 10year periods and, at the margins, trends towards longer initial validity periods as well as the absence of initial validity periods. Clearly favoured, 10-year initial periods are observed in $72 \%$ of the treaties in the sample and another $15 \%$ of treaties set 15 -year periods. ${ }^{39}$ The shortest (non-zero) validity period is less than six months, while the longest is 30 years. The average length of the initial validity period - which is 10.7 years for the entire sample - has been relatively stable since the early 1970 s. ${ }^{40}$

- Survival clauses giving treaties effect beyond the date of termination are an almost universal feature of investment treaties. The vast majority of investment treaties (97\% of the sample) have clauses that extend some or all effects of the treaty beyond termination by a fixed period during which treaty protections still hold for investments that have been made - or approved or committed - prior to termination of the treaty. The shortest fixed survival period in the sample is 5 years and the longest is 25 years. The average length of treaty effects beyond termination is 12.5 years and has been stable for many years. ${ }^{41}$

- Differences in treaty practice between BITs and non-BIT IIAs. BITs and non-BIT IIAs - e.g. Free Trade Agreements and Economic Partnership Agreements - do not generally reflect the same approach to treaty validity. Important differences can be observed with respect to the existence of an initial validity period and of effects beyond the termination of the treaties. FTAs and other nonBIT agreements typically do not set either an initial validity period nor provide for effects beyond the end termination of the treaties, features that are almost universally present in BITs. Interestingly, non-BIT IIAs almost universally provide explicitly for the possibility of treaty amendments, a feature that is relatively rare in BITs. ${ }^{42}$

39 Among the countries that participate in the FOI Roundtables, Sweden and Finland have average initial validity periods of over 16 years, while the average initial validity period of treaties concluded by Canada is less than 2 years. Kuwait, a country that does not participate in the Roundtables, stands out for having unusually long validity periods - Kuwait's treaties have an initial validity period of more than 22 years, more than twice the overall average in the sample.

See Figure 3 in Pohl, J. (2013), “Temporal Validity of International Investment Agreements: A Large Sample Survey of Treaty Provisions”, OECD Working Papers on International Investment, 2013/04.

See Figure 5 in Pohl, J. (2013), “Temporal Validity of International Investment Agreements: A Large Sample Survey of Treaty Provisions", OECD Working Papers on International Investment, 2013/04.

For a more detailed analysis of treaty clauses on amendments, see section 5 below. 


\section{Lock in effects - estimating their size and prevalence}

Initial validity periods and survival clauses lock treaty partners into their treaty obligations for extended periods of time. Thus, these features appear to be designed to advance the treaty goal of providing a stable legal framework for the protection of investments.

In order to get a sense of the size and prevalence of these effects, a hypothetical scenario has been run on the treaty sample. Under this scenario, one party to all 1,896 treaties in the sample that were known to be in force in September 2014 would decide to denounce its treaty unilaterally as soon as denunciation is legally possible. ${ }^{43}$

Figure 1. shows how this hypothetical mass "exit" would affect the share of treaties that would still have effects. The grey line shows in which year a certain fraction of treaties would be terminated given validity periods, notification requirements and renewal of validity periods. The black, broken line shows the decline, but also takes into consideration obligations resulting from survival clauses.

Most treaties in the sample have passed their initial validity periods or do not have such periods. Because of this, almost $70 \%$ of the treaties that are currently in force would be available for legal, unilateral termination within 1 year. A large number of treaties are now available for unilateral termination (see solid grey line in Figure 1.). The remaining 24\% of the treaties stay in force for longer, even for much longer: three treaties in the sample ${ }^{44}$ would remain in effect until 2034 were they denounced at the next possible occasion.

Treaty termination does not imply a complete freeing from treaty obligations, however. The provisions of existing treaties would continue to bind almost all treaty partners until at least 2025 - that is, more than $90 \%$ of treaties would still have some effect up until that date (see dotted black line in Figure 1.). Half of the treaties that are in force in 2014 continue to apply to existing investments in 2030, and in 20 years from now, in 2034, more than a quarter of the treaties would still have some effect (see dotted black line).

\footnotetext{
43 This scenario is hypothetical in more than one sense; it notably assumes that the ending of treaties would be achieved by unilateral denunciation, not by mutual agreement.

44 Egypt-Italy BIT (1989), Hungary-Kuwait BIT (1989), Italy-Vietnam BIT (1990). The Belgium/LuxembourgKuwait BIT (2000) and Lithuania-Kuwait BIT (2001) would remain in effect until 2033.
} 


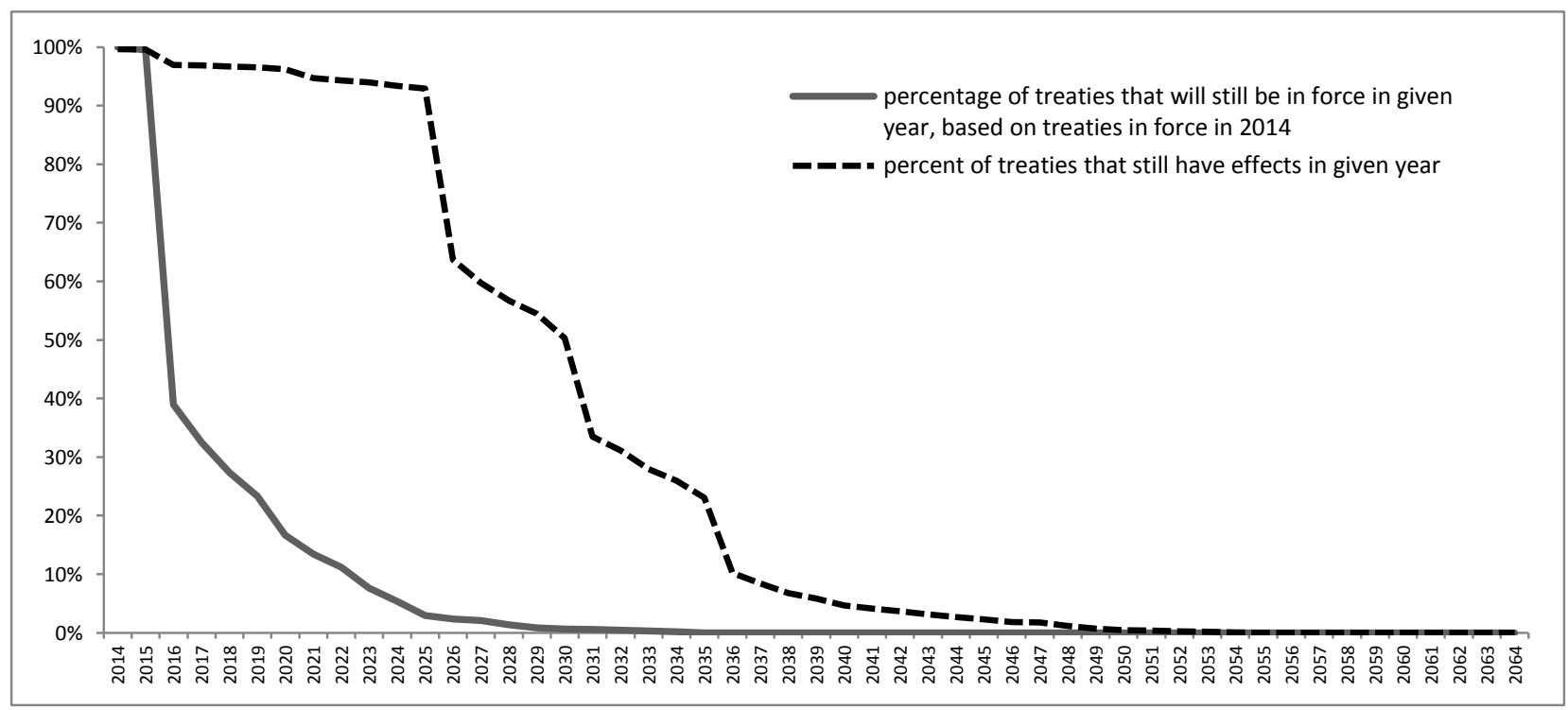

Source: OECD.

Individual countries' treaties would have quite different remaining lifespans under this hypothetical scenario. Figure 2 shows a projection of the future validity of treaties concluded by selected countries under the scenario that all treaties are denounced as soon as this can be done legally. Among these countries are the Netherlands and Belgium/Luxembourg, which have included treaty renewals for fixed periods in the large majority of their treaties (that is, the treaty provides for repeating, set validity periods, unless the treaty is denounced within a specified time period); Sweden, Germany and the United Kingdom, which generally include clauses that extend the treaty for an unlimited time after the end of the initial validity periods; and Canada, which does generally not include initial validity periods in its treaties and permits treaty denunciation at any time.

Treaty parties' decisions to opt (or not) for the automatic renewal of the treaty validity for fixed periods are the main drivers for the different speeds at which these countries' treaty numbers would shrink. Countries that have included renewals for fixed terms in their treaties would experience a much slower decline in their treaty numbers than countries that allow for denunciation at any time, including after an initial validity period. The other determining factors - treaty age and length of the initial validity periods have a lesser effect on the pace of the decline: The slower decline of the number of Sweden's treaties is explained by the country's fairly long initial validity periods in combination with a relatively high number of recently-concluded treaties. The United Kingdom, in contrast, would see the number of its treaties in force decline steeply, given that, compared to Sweden's treaties, the country's treaties have short initial validity periods and are relatively old, so that their initial validity periods have by now expired. 
Figure 2. Projection of future validity of treaties concluded by selected countries

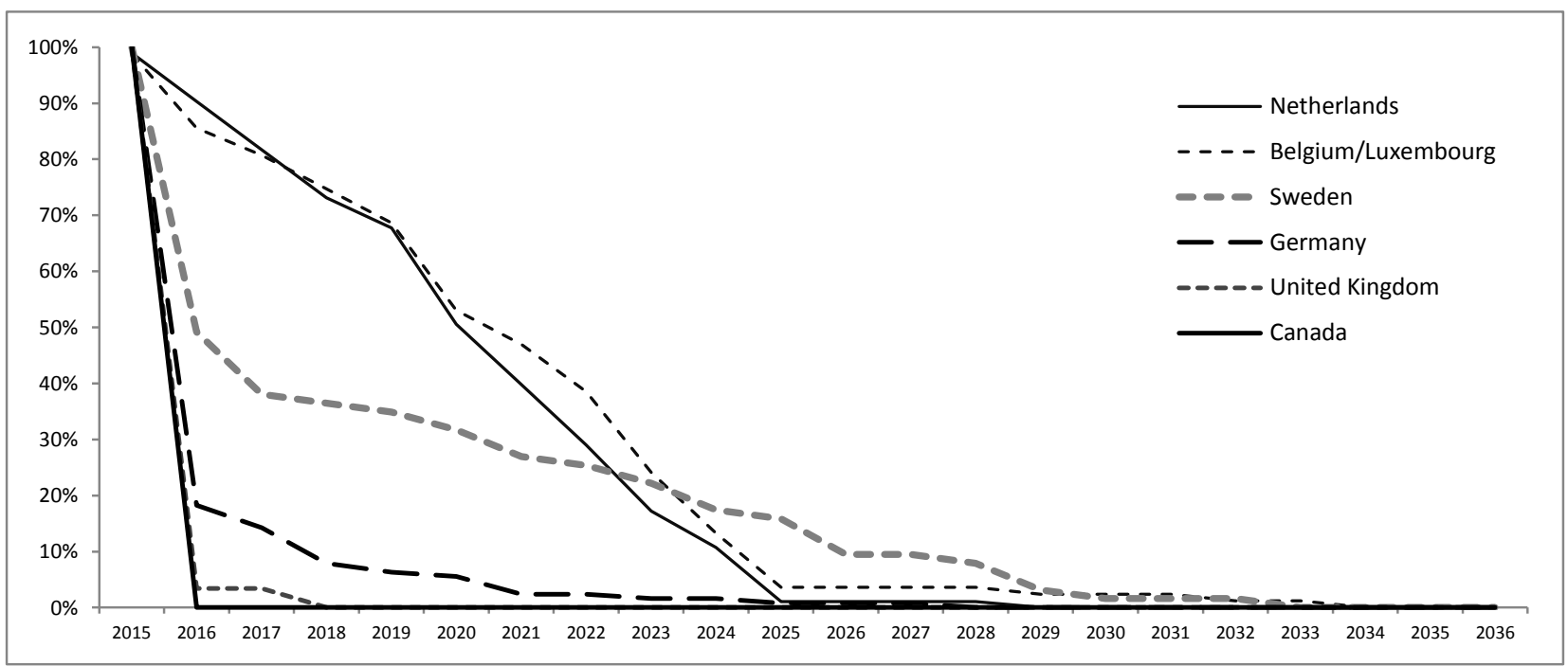

Source: OECD. 


\section{Options for voice - how governments can influence their positioning in the international investment law system}

'Voice' refers to the act of influencing the functioning of an organisation or system (e.g. the investment treaty system) from within that organisation or system (e.g. as a country with on-going investment treaty obligations). In the area of international investment law, states can express voice in various ways. These include: a) means that States may use to influence the interpretation of their treaties by treaty users; b) built-in treaty mechanisms that permit States to influence treaty interpretation; and c) treaty amendments or replacements. ${ }^{45}$

a.

Means that States may use to influence the interpretation of international investment agreements

Rules for investment treaty interpretation stem both from language in the investment treaties themselves and from the broader body of international law. Investment treaties themselves have been found to contain only very rarely any interpretive guidance for treaty users. ${ }^{46}$ Explicit mechanisms that have been found in IIAs include the possibility for submissions by non-disputing parties as well as rules on authentic interpretations by the treaty parties.

The rules contained in individual treaties, if any, are complemented by the general rules on the interpretation of treaties contained in the Vienna Convention on the Law of Treaties (VCLT), in particular its Section 3 (Articles 31-33), which apply to all treaties, including investment treaties:

\section{SECTION 3. INTERPRETATION OF TREATIES}

Article 31: General rule of interpretation

1. A treaty shall be interpreted in good faith in accordance with the ordinary meaning to be given to the terms of the treaty in their context and in the light of its object and purpose.

2. The context for the purpose of the interpretation of a treaty shall comprise, in addition to the text, including its preamble and annexes:

(a) any agreement relating to the treaty which was made between all the parties in connection with the conclusion of the treaty;

(b) any instrument which was made by one or more parties in connection with the conclusion of the treaty and accepted by the other parties as an instrument related to the treaty.

3. There shall be taken into account, together with the context:

(a) any subsequent agreement between the parties regarding the interpretation of the treaty or the application of its provisions;

(b) any subsequent practice in the application of the treaty which establishes the agreement of the parties regarding its interpretation;

(c) any relevant rules of international law applicable in the relations between the parties.

4. A special meaning shall be given to a term if it is established that the parties so intended.

45 In a paper released in December 2013, Anne van Aaken introduces a different categorisation by the time of the intervention relative to an arbitral decision, "Control Mechanisms in International Investment Law", Law and Economics Research Paper Series, University of St. Gallen Law School, Working Paper No. 2013-23 December 2013, p. 10.

46 Pohl, J., K. Mashigo and A. Nohen (2012), "Dispute Settlement Provisions in International Investment Agreements: A Large Sample Survey”, OECD Working Papers on International Investment, 2012/02. 


\section{Article 32: Supplementary means of interpretation}

Recourse may be had to supplementary means of interpretation, including the preparatory work of the treaty and the circumstances of its conclusion, in order to confirm the meaning resulting from the application of article 31 , or to determine the meaning when the interpretation according to article 31 :

(a) leaves the meaning ambiguous or obscure; or

(b) leads to a result which is manifestly absurd or unreasonable.

Article 33: Interpretation of treaties authenticated in two or more languages

$[\ldots]$

Vienna Convention on the Law of Treaties

Article 31 of the Vienna Convention on the Law of Treaties mentions a number of elements that need to be taken into account for the treaty interpretation, notably

- $\quad$ the terms of the treaty (art. 31(1) VCLT);

- any agreement relating to the treaty which was made between all the parties in connection with the conclusion of the treaty (art. 31(2)a. VCLT);

- any instrument which was made by one or more parties in connection with the conclusion of the treaty and accepted by the other parties as an instrument related to the treaty (art. 31(2)b. VCLT);

- any subsequent agreement between the parties regarding the interpretation of the treaty or the application of its provisions (art. 31(3)a. VCLT);

- any subsequent practice in the application of the treaty which establishes the agreement of the parties regarding its interpretation; (art. 31(3)b. VCLT);

- any relevant rules of international law applicable in the relations between the parties (art. 31(3)c. VCLT). ${ }^{47}$

These interpretative rules establish mechanisms for parties to investment agreements that wish to exercise voice on their existing treaties:

\section{Careful treaty drafting}

The primary way for treaty parties to ensure that treaty interpretations are closely aligned with their intent is to craft treaty language carefully. During negotiations, drafters need to anticipate how their treaty provisions will be understood by outside users (and, above all, by arbitration panels) and to provide clear guidance for interpretation. If treaties are not drafted clearly, arbitration panels cannot be expected to provide cogent and consistent awards.

As noted earlier in this paper, the language in many investment treaties is (perhaps unavoidably) vague. However, previous OECD work mapping treaty provisions has shown major differences in language - in both broad approaches to drafting and in 'micro' differences across treaties in language across dealing with identical concepts. It also shows that treaties are often silent on crucial issues of

$47 \quad$ Emphasis added to this quote from the VCLT. 
substance and procedure. ${ }^{48}$ Thus, treaties are characterised by silence on many important matters and variations across treaties in language dealing with a given subject matter.

There is some evidence that governments are increasingly aware of the need for tighter drafting of investment treaties. The survey of ISDS provisions shows that, although treaty regulation of the arbitration process tends to be "light," 49 the number of ISDS issues covered by investment treaties has increased over time - thus, governments appear to be providing more extensive guidance on how arbitrations are to be conducted. Likewise, an analysis of treaty amendments and a pair-wise, before-and-after comparison of treaties that have been replaced by new treaties shows that the more recent treaties contain more detailed language and seek to clarify key concepts (e.g. new language on 'fair and equitable' treatment; see below for details).

Some countries introduce clarifications in newer treaties with the intent to make them applicable to existing treaties that do not contain such text. The language "for greater clarity,...", now found in numerous provisions in treaties concluded in particular under a NAFTA-inspired approach, suggests that there is no substantive change of treaty provisions between the treaties with or without the clarification, and that the clarifications would also apply to treaties without this language.

$$
\text { Joint or unilateral instruments clarifying meaning and treaty parties' intent }
$$

Once an investment treaty has been adopted, treaty partners can use additional devices such as side agreements, protocols, understandings or exchanges of letters to clarify further their meaning. ${ }^{50}$ In addition, a number of tools may be used at the time of concluding the treaties. These include joint instruments that are agreed to by all parties to the treaty e.g. side agreements, protocols and exchanges of letters.

Unilateral instruments include statements and documents constituted in the course of the ratification process. These include letters and memorials to government or legislature, commentaries, official statement and parliamentary debate.

Pleadings filed by respondent governments for ISDS cases

As noted above, the majority of countries with investment treaties have already responded to at least one treaty claim. Their filings for these cases are therefore one of the most often-used communications channels for governments airing their views on how their treaties should be interpreted.

Regarding the interpretive value of these pleadings, one commentator states: "Pleadings by one treaty party alone cannot constitute evidence of an agreement, but where a respondent makes general submissions

Pohl, J., K. Mashigo and A. Nohen (2012), "Dispute Settlement Provisions in International Investment Agreements: A Large Sample Survey”, OECD Working Papers on International Investment, 2012/02; see in particular, final section on 'Key Findings' pages 39-44.

Pohl, J., K. Mashigo and A. Nohen (2012), "Dispute Settlement Provisions in International Investment Agreements: A Large Sample Survey”, OECD Working Papers on International Investment, 2012/02, page 39.

See UNCTAD IIA Issues Note No. 3 December 2011, page 10, for more information on this tool. An interesting example is the Understanding Concerning Certain U.S. Bilateral Investment Treaties, signed by the U.S., the European Commission, and acceding and candidate countries for accession to the European Union (September 22, 2003), in which the United States, the European Commission, and Acceding and Candidate Countries for accession to the European Union agreed on interpretations and specific amendments to Acceding and Candidate Countries' BITs with the U.S. to avoid incompatibilities between obligations under U.S. BITs and EU measures. 
about treaty interpretation and these are supported by the other treaty parties, they may evidence agreement. [...] When states submit pleadings they are wearing their respondent hats more clearly than at any other time. The legitimate concern arises that they might be adopting expedient interpretations to avoid liability in particular cases rather than considered interpretations that they would wish to have general application. Nevertheless, some states clearly recognise the importance of adopting interpretation that they are content to stand behind in other contexts, which leads them to take actions such as requiring pleadings to be approved by numerous government departments before filing."

$$
\text { Submissions by non-disputing parties to an investment dispute }
$$

Some treaties explicitly provide for the intervention by the other, non-disputing party or parties in arbitral proceedings. For example, in a (small) number of treaties, the non-disputing State may make submissions to an arbitration tribunal regarding questions of interpretation of the treaty in question. Article 35(1) of the (now superseded) Canada-Peru BIT (2006), for example, provided that; "on written notice to the disputing parties, the non-disputing party may make submissions to a Tribunal on a question of interpretation of this Agreement." Similarly, NAFTA article 1128 allows for the intervention of other treaty partners.

Treaties that provide explicitly for such submissions by non-disputing parties represent well under $1 \%$ of the sample.

\section{b. Built-in treaty mechanisms that permit States to influence treaty interpretation}

Some countries have built into their treaties explicit mechanisms that allow them to control the interpretation and application of their treaties more directly than through influencing interpretation. The two mechanisms identified in IIAs concern the possibility to issue authoritative interpretations of the treaty that are binding on tribunals, and consultation procedures among treaty partners in relation to prudential and tax issues when these are raised in investor-state disputes ${ }^{52}$.

Ad hoc interpretations and authoritative interpretations by treaty institutions

As stated in 31(3)a) of the VCLT (quoted above), subsequent agreements by treaty parties "shall" be taken into account in treaty interpretations. Of course, treaty parties may decide at any time to issue a statement clarifying how their treaty is to be interpreted. However, a few investment treaties provide explicitly for issuance of authoritative interpretations of treaties.

These provisions usually appear in the governing law or applicable law provisions of investment treaties. Thirty-seven of the bilateral treaties in the OECD sample of 1,660 treaties provide for such as well as three multilateral treaties with investment chapters (NAFTA, CAFTA and ASEAN). ${ }^{53}$

$51 \quad$ Anthea Roberts, 'Power and Persuasion in Investment Treaty Interpretation: The Dual Role of States' (January 12, 2010). American Journal of International Law, Vol. 104, page 217-218. Footnotes omitted.

52 In addition to consultations on prudential and tax issues, many treaties contain general consultation provisions, which are also closely linked to state to state dispute settlement and related arbitration. A separate treaty survey of these provisions can be found in DAF/INV/WD(2014)10, "State-to-State Dispute Settlement: A Survey of Investment Treaty Provisions".

Source: Treaty database used in Pohl, J., K. Mashigo and A. Nohen (2012), "Dispute Settlement Provisions in International Investment Agreements: A Large Sample Survey", OECD Working Papers on International Investment, 2012/02. This list contains treaties that provide for authoritative interpretations that are cited explicitly in the applicable or governing law provisions of the treaty. Other provisions relating to consultation 
The list of these treaties appears in Table 3. A noteworthy feature of the treaty list in Table 3 is the complete dominance of countries located in the Americas as one of the parties to these treaties. Of the 37 treaties, Mexico is a party to 22, Canada to 7 and the United States to 4 . The remaining four treaties have Chile and Peru as one of the parties. The ASEAN Comprehensive Investment Agreement (2009) is the only exception of a treaty with the feature that does not involve a treaty partner from the Americas.

The provisions create various mechanisms for issuing authoritative interpretations. These 'governance arrangements' for authoritative interpretations are quite variable (that is, they differ in terms of who may initiate the clarification process, the formal institutional structure to be used, if any, and the timing of issuance). For example, treaties may:

- designate a specific institutions that is tasked with issuing clarifications of the meaning of the treaty $;^{54}$

- state that treaty parties may agree on authoritative interpretations without specifying a precise institutional mechanism for developing these interpretations; ${ }^{55}$ or

- provide that a disputing party or the arbitration tribunal itself may call for an authoritative interpretation. ${ }^{56}$

In principle, these formal provisions have advantages over scenarios where treaty partners simply issue ad hoc clarifications. According to one commentator, when "an investment treaty specifically incorporates rules on subsequent agreements and practice these form part of the treaty's general regulatory framework. Investors take their investment rights, and tribunals take their adjudicatory powers, subject to the interpretive rights reserved by the treaty parties. This is not a case of giving unqualified rights and later

and resolution of state-to-state disputes are not included in this sample, though they may also give rise to subsequent agreements among treaty partners.

NAFTA (1992) Article 1131 states: “1. A Tribunal established under this Section shall decide the issues in dispute in accordance with this Agreement and applicable rules of international law. 2. An interpretation by the [Free Trade] Commission of a provision of this Agreement shall be binding on a Tribunal established under this Section." See also Chile-Peru FTA (2006) Artículo 11.22(2): "Derecho Aplicable: 2. Una decisión de la Comisión Administradora en la que se declara la interpretación de una disposición de este Acuerdo, conforme a lo dispuesto en el artículo 15.1 (Comisión Administradora) será obligatoria para el Tribunal que se establezca de conformidad con esta Sección y todo laudo deberá ser compatible con esa decisión." (The format of these quotes has been changed for the purposes of the present paper).

United States-Uruguay BIT (2005) Art 30 Governing Law, alinea 3 states: "A joint decision of the Parties, each acting through its representative designated for purposes of this Article, declaring their interpretation of a provision of this Treaty shall be binding on a tribunal, and any decision or award issued by a tribunal must be consistent with that joint decision."

56 For example, Article 40 of the ASEAN Comprehensive Investment Agreement (2009) states: "The tribunal shall, on its own account or at the request of a disputing party, request a joint interpretation of any provision of this Agreement that is in issue in a dispute. The Member States shall submit in writing any joint decision declaring their interpretation to the tribunal within 60 days of the delivery of the request. ... if the Member States fail to issue such a decision within 60 days, any interpretation submitted by a Member State shall be forwarded to the disputing parties and the tribunal, which shall decide the issue on its own account." (Format has been changed for the purposes of the present paper). 
infringing them; rather the rights granted were qualified in the first place. Such a framework substantially reduces concerns about detrimental reliance by investors...". ${ }^{57}$

In practice, experiences in an arbitration context with these ex post interpretive statements by treaty partners have been mixed:

- Consultations were used in CME vs. Czech Republic to arrive at a common position between the Dutch and Czech governments with regard to the BIT's interpretation. The tribunal used this joint act to support its findings. ${ }^{58}$

- NAFTA Free Trade Commission interpretations. According to one commentator, "interpretations issued by the NAFTA Free Trade Commission provoked a wide spectrum of responses by NAFTA tribunals. At one extreme, the Pope\&Talbot tribunal viewed the interpretation as an illegitimate attempt to amend the treaty retroactively in order to interfere with an on-going case. The tribunal asked pointed questions about the propriety of Canada's participation in the FTC's deliberations while it was a party to a dispute and how Canada's taking such a role could be squared with due process. At the other extreme, the ADF Group tribunal accepted the interpretation on the basis that 'we have the Parties themselves - all the Parties - speaking to the Tribunal' and '[n]o more authentic and authoritative source of instruction on what the Parties intended to convey in a particular provision of NAFTA, is possible.' The tribunal also rejected the argument that it was impliedly authorized to distinguish between FTC interpretations and amendments, noting that such an approach would 'tend to degrade and set at naught the binding and overriding character of FTC interpretations.' In these responses, the tribunals evidenced different understandings of the role of states as both respondents and treaty parties and of the nature of their own interpretive power."

57 Anthea Roberts, 'Power and Persuasion in Investment Treaty Interpretation: The Dual Role of States' (January 12, 2010). American Journal of International Law, Vol. 104, p. 208.

UNCTAD IIA Issues Note No. 3 December 2011, page 11. 
Table 3. Treaties in sample with language on authoritative interpretations by treaty partners

\begin{tabular}{|l|l|}
\hline Argentina-Mexico BIT (1996) & Korea-Mexico BIT (2000) \\
\hline Australia-Chile FTA (2008) & Mexico-Belarus BIT (2008) \\
\hline Australia-Mexico BIT (1994) & Mexico-Bolivia FTA (1994) \\
\hline Canada-Chile FTA (1996) & Mexico-Cuba BIT (2001) \\
\hline Canada-Colombia FTA (2008) & Mexico-Netherlands BIT (1998) \\
\hline Canada-Czech Republic BIT (2009) & Mexico-Nicaragua FTA (1997) \\
\hline Canada-Jordan BIT (2009) & Mexico-Panama BIT (2005) \\
\hline Canada-Panama FTA (2010) & Mexico-Slovakia BIT (2007) \\
\hline Canada-Peru FTA (2008) & Mexico-Spain BIT (2006) \\
\hline Canada-Venezuela BIT (1996) & Mexico-Switzerland BIT (1995) \\
\hline Chile-Colombia FTA (2006) & Mexico-Trinidad and Tobago BIT (2006) \\
\hline Chile-Mexico FTA (1998) & Mexico-United Kingdom BIT (2006) \\
\hline Chile-Peru FTA (2006) & Mexico-Uruguay FTA (2003) \\
\hline Colombia-Peru BIT (1994) & United States-Oman FTA (2006) \\
\hline Costa Rica-Mexico FTA (1994) & United States-Rwanda BIT (2008) \\
\hline Czech Republic-Mexico BIT (2002) & United States-Singapore FTA (2003) \\
\hline Greece-Mexico BIT (2000) & United States-Uruguay BIT (2005) \\
\hline Iceland-Mexico BIT (2005) & CAFTA (2004) \\
\hline India-Mexico BIT (2007) & NAFTA (1992) \\
\hline Japan-Mexico EPA (2004) & ASEAN Comprehensive Investment Agreement (2009) \\
\hline
\end{tabular}

Source: OECD.

Joint determinations on the nature of tax or prudential measures

Some treaties - especially more recent treaties concluded by Canada, Colombia, the United States and Peru - contain mechanisms that reserve States Parties the power to make joint determinations on individual tax and prudential measures. ${ }^{60}$ While the scope of these mechanisms' application, the procedures and consequences vary among treaties, their common feature is that they give specialised tax or financial authorities of the treaty partners an opportunity to express a common view on a specific measure that arises in a specific investor claim against one of these States Parties. This common determination bars access to ISDS, precludes basing a claim on certain treaty provisions, or binds arbitral tribunal's decision on the subject matter.

The mechanisms seem to appear for the first time in IIAs concluded in 1994, and are observed rather frequently since the mid-2000s. Overall, treaties with this feature are rare, however. Only $3.6 \%$ of the 2,060 treaties in the sample analysed for this feature contain a clause related to tax measures, and $2 \%$ of the treaties contain a clause related to prudential measures. Less than half of the countries that participate in the FOI Roundtables have concluded at least one treaty that contains such a mechanism for tax measures, and less than a third of the Roundtable participants have concluded a treaty with such a mechanism for prudential measures.

60 Treaties with this feature related to tax include for instance Canada-Benin BIT (2013), Canada-China BIT (2012), Canada-El Salvador BIT (1999), Canada-Peru BIT (2006), Canada-Peru FTA (2008), CanadaPhilippines BIT (1995), China-Peru FTA (2009), Korea-Peru FTA (2011), Peru-Guatemala FTA (2011), PeruPanama FTA (2011), Peru-Singapore FTA (2008), Peru-United States FTA (2006), United States-Uruguay BIT (2005) and United States Model BIT (2012). This feature with respect to prudential matters is included for instance in Canada-El Salvador BIT (1999), Canada-Latvia BIT (1995), Canada-Peru BIT (2006), CanadaPhilippines BIT (1995) and United States Model BIT (2012). 
The joint determination in the area of tax typically concerns whether a tax measure constitutes an expropriation. The typical treaty arrangement provides that, where the tax authorities agree that this is not the case, the investor is barred from bringing a case to dispute settlement. ${ }^{61}$ Some treaties establish a similar procedure for the question whether a measures is a taxation measure in the first place, and the decision of the states shall bind any tribunal. ${ }^{62}$

For prudential measures, Canada has included provisions in some of its treaties ${ }^{63}$ that require arbitral tribunals to seek a report from the contracting parties on "whether and to what extent the [exceptions for

$61 \quad$ E.g. China-Peru FTA (2009), Art. 142 (6). States: "If an investor invokes Article 133 (Expropriation) and Annex 9 (Expropriation) of this Chapter as the basis of a claim to arbitration according to Article 139 (Investor-State Dispute Settlement), the following procedure shall apply: The investor must first refer to the competent tax authorities described in subparagraph 7(c), at the time that it gives written notice of intent under Article 139 (Investor-State Dispute Settlement), the issue of whether the tax measure concerned involves an expropriation. In case of such referral, the competent tax authorities shall consult. Only if, within 6 months of the referral, they do not reach an agreement that the measure does not involve an expropriation, or in case the competent tax authorities of the Parties fail to consult with each other, the investor may submit its claim to arbitration under Article 139 (Investor-State Dispute Settlement).” Art. 21 United States Model BIT (2012) also contains such a mechanism.

E.g. China-New Zealand FTA (2008), Art. 204 (4), which provides: "4. If there is a dispute described in Article 152 [amicable settlement procedures under Investor-State Dispute Settlement] that may relate to a taxation measure, then the Parties, including representatives of their tax administrations, shall hold consultations. Any tribunal established under Article 153 [rules on the establishment of a arbitral tribunal for ISDS] shall accept a decision of the Parties as to whether the measure in question is a taxation measure."

E.g. Art. 2203 (9a) and (9b) Canada-Peru FTA (2008) on the issue of whether a measure is a taxation measure. Provide: "9. In order to give effect to paragraphs 1 to 3: - (a) Where in a dispute between Parties, an issue arises as to whether a measure of a Party is a taxation measure, either Party may refer the issue to the designated authorities of the Parties. The designated authorities shall decide the issue of whether the measure is a taxation measure, and their decision shall bind any panel established pursuant to Article 2106 (Dispute Settlement - Establishment of a Panel) for the dispute. Where the designated authorities have not decided the issue within six months of the referral, the Tribunal shall decide the issue in place of the designated authorities. - (b) Where in connection with a claim by an investor of a Party, an issue arises as to whether a measure is a taxation measure, the Party that has received notice of intention to submit a claim or against which an investor of a Party has submitted a claim may refer the issue to the designated authorities of the Parties. The designated authorities shall decide the issue of whether the measure is a taxation measure, and their decision shall bind any Tribunal formed pursuant to Section B of Chapter Eight (Investment) with jurisdiction over the claim. A Tribunal seized of a claim in which the issue arises may not proceed pending receipt of the decision of the designated authorities. Where the designated authorities have not decided the issue within six months of the referral, the Tribunal shall decide the issue in place of the designated authorities. [-(c) ...]"

E.g. Canada-El Salvador BIT (1999), Canada-Latvia BIT (1995), Canada-Peru BIT (2006), CanadaPhilippines BIT (1995). The United States Model BIT (2012) also contains such a provision. The clause in the Annex-Section 5(a)-(c) of the Canada-Philippines BIT (1995) for instance read: "(a) Where an investor submits a claim to arbitration under Article XIII, and the disputing Contracting Party invokes paragraphs (1) or (2) of Article XI, the tribunal established pursuant to Article XIII shall, at the request of that Contracting Party, seek a report in writing from the Contracting Parties on the issue of whether and to what extent the said paragraphs are a valid defence to the claim of the investor. - (b) The tribunal may not proceed pending receipt of a report under this Article. Pursuant to a request received in accordance with subparagraph (a), the Contracting Parties shall proceed in accordance with Article $X V$, to prepare a written report, either on the basis of agreement following consultations, or by means of an arbitral panel. The consultations shall be between the financial services authorities of the Contracting Parties. The report shall be transmitted to the tribunal, and shall be binding on the tribunal. - (c) Where, within 70 days of the referral by the tribunal, no 
prudential reasons] are a valid defence to the claim of the investor. [...] The report is binding on the tribunal." 64

Interestingly, treaties do not appear to contain such mechanisms for any issue other than tax and prudential concerns. This may reflect the perception that special knowledge must be available to assess issues related to tax and prudential matters which are unlikely to be available to arbitration panels. It may reflect the relative power of tax and prudential supervision authorities, who may be able to impose special conditions on investment treaty negotiators. Finally, it may also reflect the heightened concerns of sovereignty (or loss of sovereignty) raised by these issues. ${ }^{65}$

Other consultation mechanisms that allow states to influence treaty interpretations

Some treaties contain similar mechanisms that allow States to influence treaty interpretation by joint consultations conducted between the treaty partners. Such mechanisms relate, in the context of the definition of investment and investor, to issues of "control" of a company or an investment; to the nationality of an investor; or to the denial of benefits for investors from third countries. While an exhaustive analysis of the full treaty sample has not been made, it appears that only Australia, Canada, and the United States use the mechanism in their treaties, and each of these states uses it for a different subject area.

Australia has included in at least 14 of its treaties, all of which are BITs, a clause under which "Any question arising out of this Agreement concerning the control of a company or an investment shall be resolved to the satisfaction of the Contracting Parties". ${ }^{66}$

Canada has included similar language in presumably only one treaty, related to the nationality, which reads: "In case of disagreement concerning the nationality of an investor, consultations shall take place between the Contracting Parties with a view to achieve a mutually satisfactory solution." ${ }^{, 7}$

The United States has included such a mechanism in at least seven of its IIAs in the context of denial of benefits. The language reads: "Each Party reserves the right to deny to any of its own companies or to a company of the other Party company the advantages of this Treaty if nationals of any third country control such company, provided that, whenever one party concludes that the benefits of this Treaty should not be

request for the establishment of a panel pursuant to subparagraph (b) has been made and no report has been received by the tribunal, the tribunal may proceed to decide the matter."

Text quoted from Canada-El Salvador BIT (1999).

E.g. China-Peru FTA (2009), footnote to Art. 141 and Peru-United States FTA (2006), footnote to Art. 22.2. The text of the China-Peru FTA (2009), the footnote to Art. 141 states: "For greater certainty, if a Party invokes Article 141 (sential Security) in an arbitral proceeding initiated under this Chapter, the corresponding tribunal hearing the matter shall find whether the exception applies."

Article 1.e) of Australia-Hong Kong, China BIT (1993). Identical or similar language can be found in Argentina-Australia BIT (1995), Australia-Egypt BIT (2001), Australia-Hong Kong, China BIT (1993), Australia-Hungary BIT (1991), Australia-Indonesia BIT (1992), Australia-Lao PDR BIT (1994), AustraliaLithuania BIT (1998), Australia-Pakistan BIT (1998), Australia-Peru BIT (1995), Australia-Philippines BIT (1995), Australia-Poland BIT (1991), Australia-Romania BIT (1993), Australia-Uruguay BIT (2001), Australia-Vietnam BIT (1991).

Art. 1 (4) of Canada-Hungary BIT (1991). 
extended to a company of the other Party for this reason, it shall promptly consult with the other Party to seek a mutually satisfactory resolution of the matter." 68

None of the mentioned treaties provide specific procedural rules on the application of the consultation mechanism and the limits of their application, although the decisions that result from the mechanisms may potentially be far-reaching. Also, the consequences of an absence of agreement between the treaty partners are not spelt out. This lean design distinguishes them from the rules on joint consultations on issues related to tax and prudential measures, which identify specific authorities, set clear timelines and foresee the potential absence of an agreement between the treaty parties.

It is also noteworthy that the treaties that contain such provisions are relatively old, and that all three countries that have used the clauses do no longer seem to include them in more recently concluded treaties. Also, the mechanisms do not appear to have inspired any treaty partner to adopt them for their own treaty practice.

\section{c. $\quad$ Treaty amendments and replacements}

The above-mentioned instruments allow states to influence the use and interpretation of existing treaty text. These mechanisms are somewhat limited in their scope when states feel the need to amend their treaty obligations more substantially. For such more substantial expressions of "voice", states may require to amend treaty text or replace the treaty entirely by a new document that better meets their policy objectives. Governments that participate in the Freedom of Investment Roundtables have noted that treaty replacements can be very costly in terms of time. Earlier treaty surveys conducted to inform intergovernmental dialogue at the Roundtables have also highlighted the difficulties of updating the entire stock of outstanding treaties as improvements in treaty practice emerge. ${ }^{69}$

68 Language taken from Art. 1 (2) of the Turkey-United States BIT (1985). Identical or similar language can be found in Egypt-United States BIT (1986), Morocco-United States BIT (1985), Turkey-United States BIT (1985), United Kingdom-Haiti BIT (1985), United States-Bangladesh BIT (1986), United States-Cameroon BIT (1986), United States-Senegal BIT (1983). $2012 / 2$. 
The law of treaties permits treaty partners to amend and modify treaties they have concluded (Art. 39 VCLT, which states: "A treaty may be amended by agreement between the parties. [...]"). In addition to this general rule, about $16 \%$ of the treaties in the sample contain language that refers explicitly to the possibility of and conditions for amendments to the treaty. ${ }^{70}$ The content of these provisions varies, but they usually contain one or more of the following elements:

- $\quad$ possibility to amend the treaty;

- requirement of mutual consent; ${ }^{71}$

- moments in time at which an amendment can take place (e.g. "at the time of entry into force or anytime thereafter", "anytime", ${ }^{72}$ at "any time after the entry into force", etc.);

- description of the procedure of obtaining an agreement (in writing, through the diplomatic channel, etc.);

- form of the amendment (e.g. protocols that are integral part of the agreement);

- $\quad$ procedures that are required to make the amendment effective;

- the date on which the amendment becomes effective.

Rarely, treaties specify or limit the purpose of possible future amendments. The only specifications but not necessarily limitations - that have been found in the treaties in the sample refer to future EU membership or the establishment of a review mechanism for Investor-State Dispute Settlement (ISDS). A few treaties explicitly mention transitional arrangements as far as investors' rights are concerned. These treaties, most of which were concluded by Malaysia, secure rights that investors may have acquired before the amendment of the treaty. ${ }^{73}$

Over time, the frequency of inclusion of references to treaty amendments has increased. Until the early 1990s, such clauses were almost entirely absent from treaties, they have steadily become more frequent, and up to $50 \%$ of recently concluded treaties contain such references. Additional Protocols that

70 This and the following text does not take into consideration the possibility, accorded in some treaties, to add or subtract the application of the treaty to a treaty partner's overseas territories.

E.g. China-Uganda BIT (2004), Finland-Indonesia BIT (2006), India-Lao PDR BIT (2000), India-Uzbekistan BIT (1999), Italy-Kenya BIT (1996), Jordan-Thailand BIT (2005), Korea-Belarus BIT (1997), Korea-Brunei Darussalam BIT (2000), Korea-Lithuania BIT (1993), Korea-Mongolia BIT (1991), Korea-Nicaragua BIT (2000), Korea-Panama BIT (2001), Korea-Spain BIT (1994), Korea-Sweden BIT (1995), Morocco-United States BIT (1985), New Zealand-Singapore CEPA (2000), New Zealand-Thailand CEPA (2005), TurkeyNigeria BIT (2011), Turkey-Pakistan BIT (1995), United Kingdom-Trinidad and Tobago BIT (1993).

E.g. Austria-Lithuania BIT (1996), Bulgaria-Indonesia BIT (2003), Colombia-India BIT (2009), Czech Republic-Malaysia BIT (1996), India-Lao PDR BIT (2000).

E.g. Malaysia-Ethiopia BIT (1998), Malaysia-Ghana BIT (1996), Malaysia-Kazakhstan BIT (1996), MalaysiaKyrgyzstan BIT (1995), Malaysia-Lebanon BIT (1998), Malaysia-Mongolia BIT (1995), Morocco-Pakistan BIT (2001), Malaysia-Slovakia BIT (2007), and Poland-Mongolia BIT (1995). Article 12 (3) of the PolandMongolia BIT (1995) reads: "This agreement may be revised by mutual consent. Any revision or termination of this Agreement shall be effected without prejudice to any right or obligation accruing or incurred under this Agreement prior to the effective date of such revision or termination." The abovementioned treaties concluded by Malaysia state: "Any alteration or modification of this agreement shall be done without prejudice to the rights and obligations arising from this Agreement prior to the date of such alteration or modification until such rights and obligations are fully implemented." 
were concluded to amend treaties that were already in force frequently introduce a clause dealing with further amendments. ${ }^{74}$

The frequency of language on treaty amendments also varies with the type of treaty. Only $14 \%$ of the BITs in the sample contain language on amendments, while $76 \%$ of non-BIT investment treaties contain such clauses.

Countries have different practices when it comes to including language on modifications in their IIAs: Turkey, Denmark and Indonesia are among the countries that regularly include clauses in treaty amendment; over or around $60 \%$ of these countries' treaties contain such language. Argentina and France, in contrast, have no such language in any of their sizeable treaty samples, and Germany, the United Kingdom and the Netherlands have included such language in less than $3 \%$ of their large respective treaty samples.

The extent to which states actually use their options for amending treaties to express 'voice' and adapt their agreements is difficult to assess. In fact, there seems to be no compilation of treaty amendments, supplementary protocols or exchanges of letters related to investment agreements; moreover, not all of these documents may be publicly available. Among the 2,061 treaties in the sample of the mentioned OECD study, 60 treaties have been found that have been amended or otherwise complemented by protocols or exchanges of letters after their signature; some treaties have been amended more than once. ${ }^{75}$ The actual number of such amendments and other forms of complements to the treaties in the sample is likely to be higher, however.

Based on this sample, state practice of amendments or complements to their IIAs suggest that both exchanges of letters or separate documents that are brought into force like the main treaty are used. Which form is chosen appears to depend somewhat on the degree of change brought to the treaty, and in some cases on the subject: Exchanges of letters appear to be used essentially for the extension of the territorial application of a treaty to overseas territories ${ }^{76}$ and minor treaty changes, clarifications or corrections. ${ }^{77}$

The majority of treaty amendments analysed in the survey is carried out through separate agreements that share the form and the procedures for their entry into force with the main treaty. These changes are typically of a more substantial nature and add or change elements or even entire sections to the treaty. In the documents that were surveyed, many such changes were motivated by requirements related to

74 Among the 47 treaty amendments included in the survey, 13 introduce a clause on treaty amendments, and 5 introduce a clause on consultations between the treaty partners.

75 The conclusion of protocols in the context of the signature of a treaty is observed more frequently. However, as these protocols are not amendments of a treaty in force and thus arguably fulfil a different function, they are not considered here. Two amendments were found that appear to have been made with a view to enable the entry into force (Protocol (2003) to Germany-Moldova BIT (1994) and Protocol (1997) to South Africa-United Kingdom BIT (1994)).

E.g. Exchange of letters (1981) to Jordan-United Kingdom BIT (1979), Exchange of letters (1986) to JordanUnited Kingdom BIT (1979), Exchange of letters (2000) to Latvia-United Kingdom BIT (1994), Exchange of letters (1999) to Romania-United Kingdom BIT (1995), and Exchange of letters (1992?) to United KingdomSingapore BIT (1975).

77 E.g. Exchange of Letters (1997) to Austria-Paraguay BIT (1993), Exchange of letters (2004) to Korea-Iran BIT (1998) Exchange of letters (1971) to Netherlands-Tunisia BIT (1963) and Exchange of letters to Malaysia-Slovakia BIT (2007). 
European Union membership, as some preambles to the amending documents explicitly state. ${ }^{78}$ These changes typically introduce exceptions to MFN and NT provisions for customs unions and clauses on essential security interests; at times, additional unrelated changes are introduced simultaneously, notably adjustments to ISDS mechanisms, ${ }^{79}$ and exceptions to MFN for tax-related matters. ${ }^{80}$

Treaty modifications also occur outside the context of a necessary adaptation to international obligations such as the new membership to a common market. In these cases, amendments introduced or modified the treaties' ISDS mechanisms, ${ }^{81}$ brought definitions of certain terms, ${ }^{82}$ or made other miscellaneous additions, including changes of the treaty's preamble. ${ }^{83}$

The frequency of treaty amendments appears to vary significantly among countries: Among the 54 countries that participate in the Freedom of Investment process, 26 countries have never recorded any amendments to any of the IIAs in the sample. Romania and the Czech Republic in turn have amended 20 and 17 of their treaties in the sample, corresponding to $24 \%$ and $21 \%$ of their sample treaties, respectively. Most of the changes signed by these countries were motivated by alignment with rules of EU membership. ${ }^{84}$

Investment treaty replacements - renegotiations resulting in new treaties

An empirical study of investment treaty renegotiation has found that 160 investment treaties of the total sample have been renegotiated. ${ }^{85}$ In the 2,061 treaty strong sample used for the survey on temporal validity of investment agreements (which only covers treaties concluded by countries invited to the Freedom of Investment Roundtable), 103 references to treaty replacements were found. ${ }^{86}$ The earliest replacement of this type was found to have occurred in 1972, but over the next 20 years, only two additional treaties were replaced. Since 1993, however, treaty replacements have taken place regularly.

Protocol (2007) to Bulgaria-India BIT (1998), Protocol (2007) to China-Romania BIT (1994), Protocol (2009) to Czech Republic-Bosnia and Herzegovina BIT (2002), Protocol (2009) to Czech Republic-FYROM BIT (2001), Protocol to Czech Republic-Morocco BIT (2001), Protocol (2003) to Lithuania-United States BIT (1998), Protocol (2010) to Romania-Bosnia and Herzegovina BIT (2001).

E.g. Protocol (2009) to Czech Republic-FYROM BIT (2001)

E.g. Protocol (2005) to Romania-Slovakia BIT (1994) and Protocol (2008) to Czech Republic-Ukraine BIT (1994).

E.g. Protocol (2000) to United States-Panama BIT (1982) and Protocol (2003) to Germany-Moldova BIT (1994).

E.g. Protocol (1996) to Korea-Romania BIT (1990).

Protocol (draft) to Slovakia-Serbia BIT (1996).

This reason is stated in the preamble of 23 protocols in the sample, e.g., Protocol (2007) to Bulgaria-India BIT (1998), Protocol (2007) to China-Romania BIT (1994), Protocol (2009) to Czech Republic-Bosnia and Herzegovina BIT (2002), Protocol (2009) to Czech Republic-FYROM BIT (2001), Protocol to Czech Republic-Morocco BIT (2001), Protocol (2008) to Czech Republic-Ukraine BIT (1994), Protocol (2003) to Czech Republic-United States BIT (1991), Protocol (2007) to Egypt-Romania BIT (1994).

See Yoram Haftel/Alexander Thompsom. "When Do States Renegotiate International Agreements? A Case of Bilateral Investment Treaties" (unpublished working paper, November 2013).

This does not count the retiring of bilateral treaties that are replaced by multilateral treaties, e.g. the replacement of the Canada-United States FTA (1987) by NAFTA (1992) and thus slightly understates the number of replacements. 
Thus, in absolute terms, treaty replacements to date remain a limited phenomenon, and no year has seen more than 9 treaty replacements. Thus, at least for the time being, as treaty amendments, treaty replacements have not been a major channel used by countries seeking to change the way their treaties are interpreted. This may reflect the high political and economic costs of treaty renegotiation and possibly the difficulty in getting both treaty partners to agree to a replacement.

Nevertheless, as new treaty production has slowed since a peak in the mid-1990s, the proportion of replacements in the overall treaty production has tended to increase since the early 2000s (Figure 3.). Thus, in recent years, the emphasis of treaty negotiations has shifted somewhat to replacing older treaties and away from creating treaties with countries with which no previous treaty relation existed.

Figure 3. The dynamics of investment treaty formation and replacement

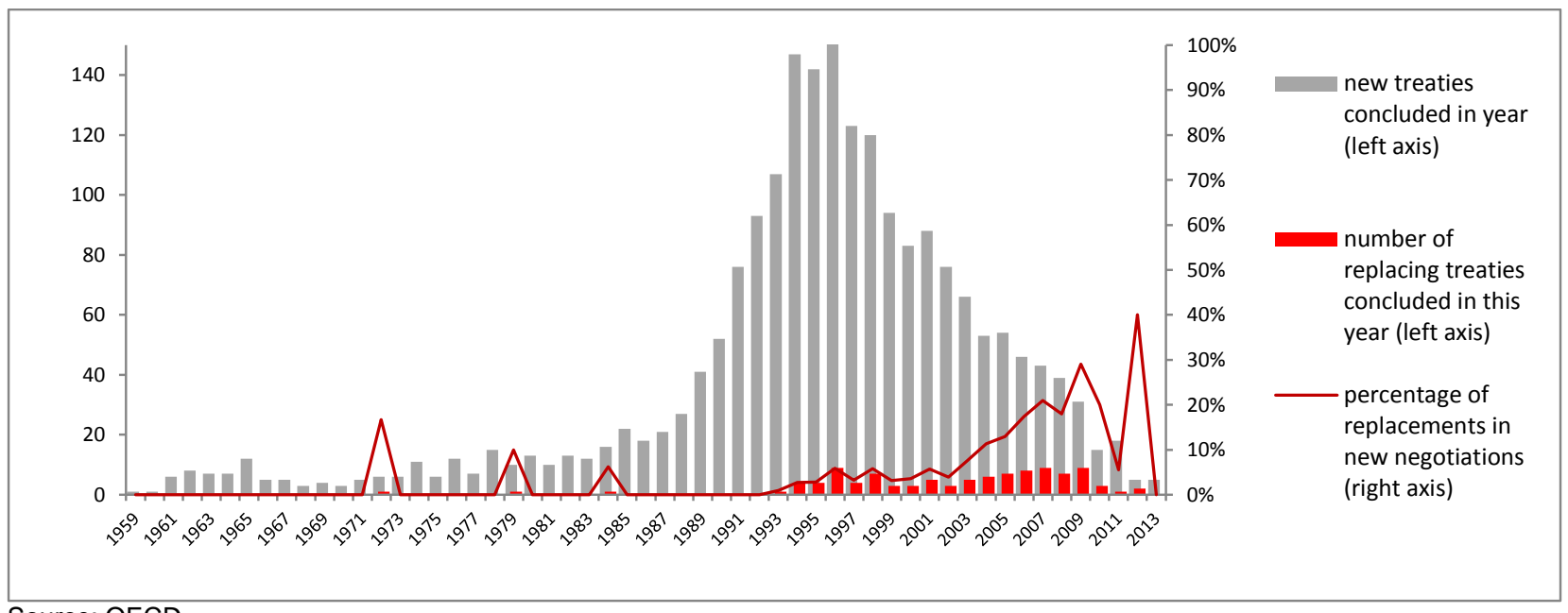

Source: OECD.

Over two thirds of the countries participating in the Roundtable have replaced at least one of their IIAs. In absolute terms, Germany and the Netherlands, have replaced the greatest number of treaties (20 and 14 cases, respectively); however, these countries are also among those having the largest - and oldest treaty samples. Most active in relative terms were Colombia, Tunisia and Canada, which replaced up to $25 \%$ of their treaties.

The age of the treaties that were replaced varied between 51 years and only 2 years; on average, treaties were 21 years old when a replacing treaty was concluded. In 13 cases, or $12.6 \%$ of the treaty replacements, a former BIT was succeeded by a non-BIT IIA (e.g. FTA or EPA). However, in 4 of these cases, the FTA suspends rather than replaces the BIT for the duration of the effect of the FTA.

Countries that replace treaties seem to be little concerned with the change for investors ${ }^{87}$ at least in comparison to their practices of treaty amendments. While at least some clauses on amendments seek to

87 See Tania S. Voon, Andrew D. Mitchell and James Munro: "Parting Ways: The Impact of Investor Rights on Mutual Termination of Investment Treaties", (2014) ICSID Review - Foreign Investment Law Journal (forthcoming) and available at http://papers.ssrn.com/sol3/papers.cfm?abstract_id=2365996. 
grandfather rights under the treaty as it stood before the amendment, ${ }^{88}$ no replacing treaty has been found in the sample that explicitly grandfathered rights acquired under the old treaty. ${ }^{89}$

In order to explore the nature of the changes to treaty language that resulted from these renegotiations, the OECD Secretariat has surveyed 38 'before and after' pairs of treaties (thus the total sample is 76 treaties) where an earlier treaty was replaced by a renegotiated treaty. That is, the Secretariat has done a pair-wise comparison of the provisions of the earlier and the replacing treaties. ${ }^{90}$ This survey - which covers provisions relating to the main substantive issues contained in the treaties (such as national treatment, fair and equitable treatment, MFN) may shed light on the nature of the legal and policy concerns that motivated the renegotiation.

Key findings are as follows:

- Longer, more detailed treaties. The treaty replacements often added detail and length to existing treaty provisions and addressed new issues. The survey analysed a total of 11 issue areas, including provisions on fair and equitable treatment, protection and security, national treatment, most favoured nation, expropriation and state-to-state dispute settlement. ${ }^{91}$ On average the renegotiations resulted in changes (usually additions) in treaty language in 6 of the 11 issue areas. Treaty negotiation also tended to result in more detailed treaty language, including by increasing detail in existing treaty provisions (especially in definition of investment and fair and equitable treatment and full protection and security) and by adding new issues.

- Changes tended to increase similarities among treaties, but major differences remain. This survey of treaty replacements confirms the findings of earlier studies that investment treaty practice across countries and across treaties remains variable. In the present survey, the treaties tend to cover the same broad set of investment protection standards, but differences in language across treaties for the same country and across countries are a noteworthy feature of the sample. Nevertheless, the treaty changes in the before-and-after comparison point (to some extent) in the direction of greater similarity among the renegotiated treaties. For example:

- Changes relating to 'fair and equitable treatment' (FET) ${ }^{92}$ and 'protection and security' (PS) provide evidence of growing similarities in language across treaties, but also continued

$88 \quad$ See for more detail above section 5.c.(1).

89 Some replacing treaties contain provisions on the application of the preceding treaty for pending disputes, however.

Countries covered (and number of replacements) are: Australia (1), Austria (1), Belgium/Luxembourg (3), Canada (6), Chile (2), China (3), Colombia (2), Costa Rica (1), Czech Republic (1), Egypt (3), France (3), Germany (13), India (1), Indonesia (1), Jordan (1), Korea (2), Latvia (1), Mexico (2), Morocco (4), Peru (3), Romania (2), Slovakia (1), Spain (2), Switzerland (3), Tunisia (1) and the United States (1). The total number of renegotiations in this list exceeds 38 because some of the renegotiations were between two countries that appear on the list.

91 The full list of 11 issue areas covered in the 'before and after' comparison is: 1. definition of investor; 2. definition of investment; 3. fair and equitable treatment; 4. protection and security; 5. national treatment; 6. most favoured nation; 7. expropriation; 8. compensation for losses; 9. prudential measures; 10. essential security interests and public order; and 11. State-to-state dispute settlement.

It is worth noting that several treaties with the unusual feature of not containing a FET provision were replaced by treaties that did contain such a provision. For example, one of the French replacements and three of the German renegotiations resulted in the addition of FET provisions, which had been absent in the earlier version of the treaties. 
variation. Four of the earlier (pre-renegotiation) treaties did not contain FET provisions, ${ }^{93}$ but their replacements all contain such provisions. While FET is now a universal feature of the renegotiated treaties, the specific language used in these provisions varies, but also shows a partial tendency toward convergence. For example, some treaties now include references to Minimum Standard of Treatment (MST) of aliens, Customary International Law or International law. While it is still the case that most of the 76 treaties analysed - that is, 54 treaties for 'protection and security' and 49 for FET - do not refer to such standards, a noticeable change is the introduction of such references in the replacement treaties. Six early treaties ${ }^{94}$ for PS and 9 early treaties for FET, contained reference to international law, and only $1^{95}$ to MST in accordance with customary international law whereas 16 recent treaties for PS and eighteen for FET contain one of these references. The reference the most used in recent treaties is the $\mathrm{MST}^{96}$ of aliens in accordance with Customary International Law and thirteen recent treaties incorporate such a reference for FET and PS.

- Provisions on national security reservations are not a standard feature of this treaty sample, but are becoming more common. Thirty-nine treaties in the 'before and after' sample mainly involving Canada and Germany, but with a few others as well - contain such provisions. National security provisions can be part of articles on exceptions ${ }^{97}$ or part of other articles. ${ }^{98}$ Thirteen treaties have incorporated such a clause in their recent versions when absent in the earlier version (4 Canadian treaties, 3 German ones, 1 Australian, 1 Chilean, 1 Chinese, 1 Egyptian, 1 Indian and 1 Mexican). Such clauses are nevertheless completely absent from the French, Belgian, Austrian, Spanish treaties in the sample.

- Definition of investment - relative stability over time and relative homogeneity across treaties, but details are added. Many of the treaties contain similar definitions of covered investments that take the form of lists including: moveable and immoveable property and other related property rights; shares and other kinds of participation in a company; debt and other claims to recover money; intellectual property (IP) rights; concession rights and good-will which is sometimes a standalone investment or associated with the IP rights. Sixty-nine treaties contain at least four of the above mentioned elements. Twenty two pairs of earlier and recent treaties contain all of these elements and keep an identical list in the original and in the re-negotiated treaties, except for goodwill which is sometimes removed from or added to the more recent treaties. These elements are nevertheless sometimes more detailed in the new treaty such as the IP rights in the BelgiumKorea BIT 2006 or the shares in the Germany Morocco BIT 2001. One difference between the earlier and the recent treaties is the addition of a definition of investments when absent in the pre-

\footnotetext{
France-Tunisia BIT (1972), Germany-Iran BIT （1965), Germany-Morocco BIT （1961), GermanyPakistan BIT (1959).

Belgium/Luxembourg-Korea BIT (1974), Canada-Latvia BIT (1995) , Canada-Peru BIT (2006), ColombiaSpain BIT (1995), Mexico-Spain BIT (1995), Morocco-United States BIT (1985).

95 Canada-Peru BIT (2006).
}

96 For instance in Canada-Romania BIT (2009), article II 2 (a): "Each Contracting Party shall accord investments or returns of investors of the other Contracting Party treatment in accordance with the customary international law minimum standard of treatment of aliens, including fair and equitable treatment and full protection and security."

97 For instance in Canada-Latvia BIT (2009), Article XVII (6).

98 For instance, Germany-Jordan BIT (2007) article 3, "Measures that have to be taken for reasons of public security and order, public health or morality shall not be deemed 'treatment less favourable"'. 
renegotiation treaty ${ }^{99}$. This new list includes all the standard elements mentioned above. Another difference is the inclusion of additional elements in the list of covered investments ${ }^{100}$.

The changes brought by treaty replacements cover areas similar to those that are addressed by treaty amendments.

Five treaties, the Belgium/Luxembourg-Morocco BIT (1999), France-Morocco BIT (1996), France-Philippines BIT (1994), France-Tunisia BIT (1997), and Germany-Sri Lanka BIT (2000), incorporate a definition with a list of covered investments that did not appear in the earlier treaty.

100 Nine recent treaties have added elements to the list such as Enterprise, Bonds and other debt instruments, Future options and other derivatives or Loan to an enterprise. This change most frequently occurred when changing from a BIT to a FTA such as in the Peru-Singapore FTA (2008) or the India-Korea CEPA (2009) although it occurred in one recent BIT (Mexico-Spain BIT (2006)). Four new treaties add other types of investment to the list but also detail the investments that are not covered by the agreement such as the Colombia-Spain BIT (2005) or the Australia-Chile FTA (2008). 


\section{Conclusions}

This paper suggests that investment treaties provide for significant amounts of stability in the legal framework for the protection of investment (via long validity and survival clauses), but that most remain silent on issues of government voice. International law makes numerous options available to treaty partners wishing to influence treaty interpretation, but few countries seem to avail themselves of these options. Furthermore, experiences with ISDS tribunals' use of, for example, authoritative interpretations by treaty partners have been mixed.

A number of OECD surveys suggest that treaty partners are trying to make their treaty language more detailed on substance and procedure - this is arguably the most important avenue for state influence on treaty interpretation. However, beyond treaty drafting, most governments provide little or no input into the treaty interpretation process, aside from their filings when they respond to ISDS claims.

This reluctance to take steps to influence treaty interpretation may indicate that most countries consider that there is no need to provide such inputs or because they do not wish to be perceived as interfering with treaty-based dispute settlement.

Other countries, in contrast, are concerned about the way their treaties are being used and interpreted and are seeking ways of changing their positioning vis-à-vis investment treaty law, including via exit. Providing for more government voice could enhance the benefits from and long term viability of investment treaty law by making it more responsive to treaty partners' evolving needs and circumstances and by decreasing incentives for countries to withdraw from the treaty system. 


\title{
OECD Working Papers on International Investment
}

\author{
www.oecd.org/daf/inv/investment-policy/working-papers.htm
}

2015/1 The Policy Landscape for International Investment by Government-Controlled Investors: A Fact Finding Survey

2014

2014/3 Investment Treaties and Shareholder Claims: Analysis of Treaty Practice

2014/2 Investment Treaties and Shareholder Claims for Reflective Loss: Insights from Advanced Systems of Corporate Law

2014/1 Investment Treaty Law, Sustainable Development and Responsible Business Conduct: A Fact Finding Survey

\section{3}

2013/4 Temporal validity of international investment agreements: a large sample survey of treaty provisions

2013/3 Investment treaties as corporate law: Shareholder claims and issues of consistency

2013/2 Lessons from Investment Policy Reform in Korea

2013/1 China Investment Policy: an Update

2012

$2012 / 3$

Investor-state dispute settlement: A scoping paper for the investment policy community

2012/2 Dispute settlement provisions in international investment agreements: A large sample survey

2012/1 Corporate greenhouse gas emission reporting: A stocktaking of government schemes

2011/2 Defining and measuring green FDI: An exploratory review of existing work and evidence

2011/1 Environmental concerns in international investment agreements: a survey

2010

2010/3 OECD's FDI Restrictiveness Index: 2010 Update

2010/2 Foreign state immunity and foreign government controlled investors

2010/1 Intellectual property rights in international investment agreements

2006

2006/4 OECD's FDI regulatory restrictiveness index: Revision and extension to more economies

2006/3 Interpretation of the Umbrella Clause in Investment Agreements

2006/2 Investor-State Dispute Settlement in Infrastructure Projects

2006/1 Improving the System of Investor-State Dispute Settlement: An Overview 
2005/3 Corporate Responsibility Practices of Emerging Market Companies - A Fact-Finding Study

2005/2 Multilateral Influences on the OECD Guidelines for Multinational Enterprises

2005/1 Transparency and Third Party Participation in Investor-State Dispute Settlement Procedures

\section{4}

2004/6 Mobilising Investment for Development: Role of ODA - The 1993-2003 Experience in Vietnam

2004/5 ODA and Investment for Development: What Guidance can be drawn from Investment Climate Scoreboards?

2004/4 Indirect Expropriation and the Right to Regulate in International Investment Law

2004/3 Fair and Equitable Treatment Standard in International Investment Law

2004/2 Most-Favoured-Nation Treatment in International Investment Law

2004/1 Relationships between International Investment Agreements

2003

$2003 / 2$

$2003 / 1$

2002

$2002 / 2$

$2002 / 1$

2001

2001/6 Codes of Corporate Conduct: Expanded review of their contents

2001/5 The OECD Guidelines for Multinational Enterprises and other corporate responsibility instruments

2001/4 Public policy and voluntary initiatives: What roles have governments played?

2001/3 Making codes of corporate conduct work: Management control systems and corporate responsibility

2001/2 Corporate Responsibility: Results of a fact-finding mission on private initiatives

2001/1 Private Initiatives for Corporate Responsibility: An Analysis

\section{0}

2000/5 Recent trends, policies and challenges in South East European countries

2000/4 Main determinants and impacts of FDI on China's economy

2000/3 Lithuania: Foreign Direct Investment Impact and Policy Analysis

2000/2 Investment Patterns in a Longer-Term Perspective

2000/1 Bribery and the business sector: Managing the relationship

1999

1999/3 Rules for the Global Economy: Synergies between Voluntary and Binding Approaches

1999/2 Deciphering Codes of Corporate Conduct: A Review of their Contents

1999/1 Southeast Asia: the Role of FDI Policies in Development

1998

1998/1 Survey of OECD work on international investment 